\title{
Revisionary study of the armored catfish Corydoras paleatus (Jenyns, 1842) (Siluriformes: Callichthyidae) over 180 years after its discovery by Darwin, with description of a new species
}

\author{
Luiz Fernando Caserta Tencatt ${ }^{1}$, Marcelo Ribeiro de Britto ${ }^{2}$ and \\ Carla Simone Pavanelli1,3
}

\begin{abstract}
The taxon known as Corydoras paleatus carries one of the most complex taxonomic histories among Corydoradinae catfishes. A comprehensive review of specimens attributed to that species from several localities was carried out, allowing the clear recognition of $C$. paleatus and also of a new species previously misidentified as C. paleatus, described herein. Corydoras paleatus can be distinguished from its congeners by presenting the following unique combination of features: perpendicularly directed serrations along entire posterior margin of the pectoral spine; three large black blotches along midline of flank; hyaline or black pectoral fin; and transversal black bars on caudal-fin lobes. Corydoras paleatus is known from the lower rio Paraná basin, coastal rivers from Southern Brazil and Uruguay and rio Uruguai basin. The new species can be distinguished from its congeners by having the following unique combination of features: three large black blotches along midline of flank; three nasal pores; mesethmoid short; infraorbital 2 not in contact with compound pterotic; striated black spots from the snout tip to nuchal plate region; markedly rounded snout; and anterior portion of dorsal fin spotted. The new species is known from the upper rio Uruguai basin, from the rivers Canoas, do Peixe and Pelotas.

O táxon conhecido como Corydoras paleatus carrega uma das histórias taxonômicas mais complexas dentre os bagres Corydoradinae. Uma revisão abrangente de espécimes atribuídos a essa espécie, de várias localidades, foi conduzida. A análise do material colhido permitiu o reconhecimento claro de $C$. paleatus e também de uma espécie nova, previamente identificada erroneamente como C. paleatus, aqui descrita. Corydoras paleatus pode ser distinguida de suas congêneres por possuir a seguinte combinação única de características: serrilhas perpendicularmente direcionadas ao longo de toda a margem posterior do acúleo peitoral; três manchas pretas grandes ao longo da linha mediana do flanco; nadadeira peitoral hialina ou preta; e barras transversais pretas nos lobos da nadadeira caudal. Corydoras paleatus é conhecida da bacia do baixo rio Paraná, rios costeiros do sul do Brasil e Uruguai, e bacia do rio Uruguai. A espécie nova pode ser distinguida de suas congêneres por possuir a seguinte combinação única de caracteres: três manchas pretas grandes ao longo da linha mediana do flanco; três poros nasais; mesetmóide curto; infraorbital 2 não contatando o pterótico composto; manchas pretas estriadas da ponta do focinho até a região da placa nucal; focinho marcadamente arredondado; e porção anterior da nadadeira dorsal com manchas. A espécie nova é conhecida da bacia do alto rio Uruguai, dos rios Canoas, do Peixe e Pelotas.
\end{abstract}

Keywords: Corydoradinae, Corydoras longipinnis, rio de La Plata basin, Taxonomy, Uruguay.

\section{Introduction}

Corydoras Lacépède, 1803, with approximately 170 valid species, is the most species-rich genus of the Callichthyidae and also of Siluriformes (Eschmeyer, 2015). Despite the extensive studies regarding the taxonomy and systematics of Corydoras (e.g. Gosline, 1940; Nijssen, 1970; Nijssen \& Isbrücker, 1980; Britto, 2003; Alexandrou et al., 2011), the clear recognition of many species is still unclear.
The taxon known as Corydoras paleatus was originally described as Callichthys paleatus by Jenyns in 1842, based on material collected by Charles Darwin, during his circumnavigation voyage on board the ship HMS Beagle, in the years 1831 to 1836 . As recorded by Jenyns (1842: 114), the five specimens of Callichthys paleatus, which were brought to England by Darwin, had lost their attached labels that contained corresponding numbers in Darwin's manuscripts with noted localities. The species description

\footnotetext{
${ }^{1}$ Universidade Estadual de Maringá. Programa de Pós-Graduação em Ecologia de Ambientes Aquáticos Continentais, Av. Colombo, 5790, 87020-900 Maringá, Paraná, Brazil. luiztencatt@hotmail.com (corresponding author)

${ }^{2}$ Universidade Federal do Rio de Janeiro, Museu Nacional, Departamento de Vertebrados, Setor de Ictiologia, Quinta da Boa Vista s/n, São Cristóvão, 20940-040 Rio de Janeiro, Rio de Janeiro, Brazil. mrbritto2002@yahoo.com.br

${ }^{3}$ Núcleo de Pesquisas em Limnologia, Ictiologia e Aquicultura, Universidade Estadual de Maringá, Av. Colombo, 5790, 87020-900 Maringá, Paraná, Brazil. carlasp@nupelia.uem.br
} 
was also marked by somewhat general or dubious characters and by lacking figures, which made difficult its unequivocal recognition. For example, Jenyns (1842: 113) reported the presence of a row of minute teeth on each jaw and vomer. However, jaws in Corydoradinae catfishes are edentulous (Reis, 1998; Britto, 2003), and an edentulous vomer is present in most of catfish families, including loricarioids (Regan, 1911; Mo, 1991; de Pinna, 1993; Britto, 2002).

Eigenmann \& Eigenmann (1890) were the first authors to place Callichthys paleatus in Corydoras, proposing the new combination $C$. paleatus. In addition to it, the authors placed Corydoras marmoratus Steindachner, 1879 as junior synonym of $C$. paleatus, alleging that its illustration (Steindachner, 1879: pl. V, fig. 1) exactly fits Jenyns' description (p. 471). Eigenmann \& Eigenmann examined three specimens of $C$. paleatus from Uruguay, and also assigned La Plata and tributaries as the species habitat.

In his revision of Corydoras, Regan (1912) followed Eigenmann \& Eigenmann (1890) on the taxonomy of $C$. paleatus, and additionally placed Corydoras ehrhardti Steindachner, 1910 in its synonymy (p. 212). Regan also doubtfully assigned Corydoras aurofrenatus Eigenmann \& Kennedy, 1903 and the two species and one subspecies described by Ihering (1911), i.e. C. meridionalis, $C$. flaveolus and $C$. nattereri triseriatus, as junior synonyms of C. paleatus. Additionally, Regan (1912) extended the distributional range of C. paleatus far beyond Eigenmann \& Eigenmann (1890), based on the data of 12 specimens from Buenos Aires, Cordoba (Argentina), Paraná, Joinville and Rio Grande do Sul (Brazil). Gosline (1940: 21), in his revision of the Callichthyidae, followed Regan's (1912) statement, except for $C$. aurofrenatus, which he considered a valid species (p. 22). Gosline (1940) attempted to justify the synonym of $C$. ehrhardti explaining that Regan has examined syntypes (=cotypes) of that species, considering it indistinguishable from C. paleatus (indeed, Regan (1912: 212) listed just one syntype of $C$. ehrhardti). Gosline also commented about Ihering (1911) species as unidentifiable forms that may or may not be assigned to C. paleatus. Weitzman (1955) redescribed Corydoras nattereri triseriatus (ranked as $C$. triseriatus in that work) and listed several evidences that it is clearly distinct from C. paleatus.

Nijssen (1970: 58) considered C. marmoratus, $C$. ehrhardti, C. meridionalis and C. flaveolus as valid, and also placed these species together with $C$. paleatus and other congeners in an assemblage called "barbatus-group". However, Nijssen furnished no evidence for the validation of those species. Nijssen \& Isbrücker (1980), in a review of Corydoras, placed C. marmoratus in the synonymy of C. paleatus. Both authors also considered Corydoras microcephalus Regan, 1912 as junior synonym of C. paleatus, as well as $C$. punctatus var. argentina Steindachner, 1879 (p. 26: a name cited in the synonymy of $C$. marmoratus that refers to C. punctatus from "Monté-Vidéo" described by Valenciennes (1840) in Cuvier \& Valenciennes, and illustrated in d'Orbigny (1847)) and Corydoras maculatus Steindachner,
1879 (p. 32: a nomem novum for the same C. punctatus recorded by Valenciennes in Cuvier \& Valenciennes (1840), and d'Orbigny (1847), but no description or definition was provided and no specimen traced). In addition, both authors restricted the type-locality of $C$. paletaus to "Argentina -

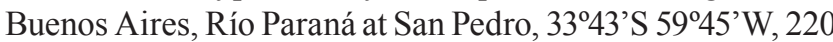
km NW of Buenos Aires" (p. 204). They also recorded that only three of the five syntypes reported by Jenyns (1842: 114) were found and designated a lectotype (BMNH 1917.7.14:18).

Isbrücker (2001), in a brief catalogue of genera and species in Corydoradinae, validated several species. As criteria, he considered distances from type-localities and information from living forms. In this way, Isbrücker (2001: 229, 230) listed C. maculatus, C. marmoratus and C. microcephalus as valid, although doubtful, species. The author considered only Silurus quadricostatus Larrañaga, 1923 and Silurus septemradiatus Larrañaga, 1923, although also doubtful, in the synonymy of $C$. paleatus. Though not mentioned, Isbrücker (2001) apparently followed the work of Devicenzi (1925) to propose such synonymy. In that work, Devicenzi (1925) provided comments for all the fish species cited by Larrañaga (1923), and assigned the correspondence between Silurus quadricostatus and S. septemradiatus with C. paleatus (see Devicenzi, 1925: 307).

Reis (2003: 301) followed Nijssen \& Isbrücker (1980) in the synonymy of Corydoras paleatus, plus Larrañaga (1923) species. Knaack (2007a) analyzed the type-series of $C$. paleatus and concluded that the specimen stated as BMNH 1917.7.14.18 was not the same specimen designated as lectotype by Nijssen \& Isbücker (1980) and declared that the true lectotype is lost, designating a neotype (BMNH 1917.7.14.19). This probably occurred because Knaack confused the labels of the lots, since the specimen presented as a possible lectotype of $C$. paleatus in fact corresponds to a specimen of the type-series of Corydoras micracanthus Regan, 1912 (see Knaack, 2007a: 28).

One year later, Knaack (2008) mentioned: "researches in the internet led to pictures of a fish, which was named as lectotype (of Callichthys paleatus). This fish is clearly a member of the series of the syntypes and the fish, which was designated as lectotype by Nijssen \& Isbrücker (1980)", considering invalid the designation of the neotype, since the supposed lost lectotype had been rediscovered. The author also provided morphometric and meristic data of the lectotype and the two paralectotypes. Despite comments and justifications presented by Knaack (2007a; 2008), the specimen designated as the lectotype of Corydoras paleatus by Nijssen \& Isbrücker (1980) was probably never lost, being only a possible mistake committed by Knaack (2007a), which may have confused the labels. Knaack (2008) did not mention any connection between the specimen presented by him as the wrongly stated C. paleatus lectotype (see Knaack, 2007a: 28) and C. micracanthus.

All the aforementioned facts contribute to cause uncertainty about Corydoras paleatus identity. Nevertheless, specimens indiscriminately attributed to $C$. paleatus have 
been used in many different kinds of studies, like behavior, physiology, fish pathology, among others (e.g. Pruzsinszky \& Ladich, 1998; Kaatz \& Lobel, 1999; Fanta et al., 2003; Cazenave et al., 2005, 2006; Pesce et al., 2008), which makes it one of the most useful corydoradine catfish in Experimental Biology. Therefore, it is important to precisely assign its limits and definition. After the analysis of several specimens from various localities, including lectotype and paralectotypes of $C$. paleatus and C. marmoratus, and the lectotype of C. microcephalus, allied to information provided in $C$. paleatus original description, it was possible to recognize the populations corresponding to C. paleatus and determine which of them refer to the species described by Jenyns (1842). Additionally, the analysis of the gathered material revealed a new species previously misidentified as $C$. paleatus, which is described herein. A redescription of $C$. paleatus is also provided to allow its clear definition and correct identification, and put a conclusive denouement about the taxonomic status of those specimens collected by Darwin around 180 years ago.

\section{Material and Methods}

Measurements were obtained using digital caliper to the nearest millimeter. Morphometric and meristic data were taken following Reis (1997) with modifications of Tencatt et al. (2013). Morphometrics are reported as percentages of standard length (SL) and head length (HL). The paralectotypes (BMNH 1917.7.14.19 and BMNH 1917.7.14.19a) of Callichthys paleatus; lectotype (NMW 5538) and paralectotypes (NMW 46775-1, NMW 467752, NMW 46776, NMW 46777-1 and NMW 46777-2) of Corydoras marmoratus, and lectotype (BMNH 1890.3.12.4) of Corydoras microcephalus were examined only through high-resolution photographs. Homology of barbels follows Britto \& Lima (2003). Some exemplars were cleared and stained (c\&s) according to protocol of Taylor \& Van Dyke (1985). Osteological terminology was based on Reis (1998), excepting by using parieto-supraoccipital instead of supraoccipital (Arratia \& Gayet, 1995), compound pterotic instead of pterotic-supracleithrum (Aquino \& Schaefer, 2002), and scapulocoracoid instead of coracoid (Lundberg, 1970). Nomenclature of latero-sensory canals and preopercular pores are according to Schaefer \& Aquino (2000) and Schaefer (1988), respectively. The supra-preopercle sensu Huysentruyt \& Adriaens (2005) were treated here as a part of the hyomandibula according to Vera-Alcaraz (2013). Vertebral counts include only free centra, with the compound caudal centra (preural 1+ ural 1) counted as a single element. In the description, numbers in parenthesis represent the total number of specimens with those counts. Numbers with an asterisk refer to the counts of the holotype.

Comparative data of Corydoras agassizii Steindachner, 1876, C. breei Isbrücker \& Nijssen, 1992, C. copei Nijssen \& Isbrücker, 1986, C. cruziensis Knaack, 2003, C. gladysae Calviño \& Alonso, 2009, C. habrosus Weitzman, 1960, C. haraldschultzi Knaack, 1962, C. isbrueckeri Knaack, 2004, C. lamberti Nijssen \& Isbrücker, 1986, C. micracanthus Regan, 1912, C. noelkempffi Knaack, 2004, C. orcesi Weitzman \& Nijssen, 1970, C. ornatus Nijssen \& Isbrücker, 1976, C. orphnopterus Weitzman \& Nijssen, 1970, C. paucerna Knaack, 2004, C. petracinii Calviño \& Alonso, 2009, C. punctatus (Bloch, 1794), C. reynoldsi Myers \& Weitzman, 1960, C. robustus Nijssen \& Isbrücker, 1980, C. spectabilis Knaack, 2000, C. steindachneri Isbrücker \& Nijssen, 1973, C. weitzmani Nijssen, 1971 and C. xinguensis Nijssen, 1972 were obtained through their original descriptions and/or high resolution photographs of type specimens hosted in the British Museum of Natural History, London. Photographs of other pertinent type specimens were available to examination through the All Catfish Inventory website (Morris et al., 2006).

The synonymic list comprised only the works from which the voucher specimens could be examined or those that provided high quality photos, allowing then the clear recognition of Corydoras paleatus. Institutional abbreviations are: AI, Asociatión Ictiológica de La Plata, La Plata; ANSP, Academy of Natural Sciences of Drexel University, Philadelphia; BMNH, Natural History Museum, London; LBP, Laboratório de Biologia de Peixes da Universidade Estadual Paulista "Júlio de Mesquita Filho", Botucatu; MCP, Museu de Ciências e Tecnologia da Pontifícia Universidade Católica do Rio Grande do Sul, Porto Alegre; MCZ, Museum of Comparative Zoology, Harvard University, Cambridge; MLP, Museo de La Plata, La Plata, Buenos Aires, Argentina; MNRJ, Museu Nacional, Universidade Federal do Rio de Janeiro, Rio de Janeiro; MZUEL, Museu de Zoologia da Universidade Estadual de Londrina, Londrina; MZUSP, Museu de Zoologia da Universidade de São Paulo, São Paulo; NMW, Naturhistorisches Museum, Wien; NRM, Naturhistoriska Riksmuseet, Stockholm; NUP, Coleção Ictiológica do Núcleo de Pesquisas em Limnologia, Ictiologia e Aquicultura da Universidade Estadual de Maringá, Maringá; ROM, Royal Ontario Museum, Toronto; UFRGS, Departamento de Zoologia da Universidade Federal do Rio Grande do Sul; ZUFMS-PIS, Coleção Zoológica de Referência da Universidade Federal de Mato Grosso do Sul, Campo Grande; ZVC-P, Colección de Peces de la Faculdad de Ciências Naturales, Montevideo.

\section{Results}

\section{Corydoras paleatus (Jenyns, 1842)}

(Figs. 1, 2, 3a, 4a, 5, 10; Table 1)

Callichthys paleatus Jenyns, 1842 (In Jenyns, 1840-42): 113-114. Corydoras marmoratus Steindachner, 1879a: 26-28, pl. V fig. 1 (partim).

Corydoras paleatus Eigenmann \& Eigenmann, 1890: 471. -Almirón et al., 2008: 124. -Casciotta et al., 2005: 77, 167, 232, fig. 88. -Almirón et al., 2015: 29, 150, 151.

Corydoras longipinnis Knaack, 2007: 36; 39, figs. 5, 6 and 7; 43, fig. 12 (partim).

Corydoras cf. paleatus Calviño \& Alonso, 2009: 207, fig. 5. 


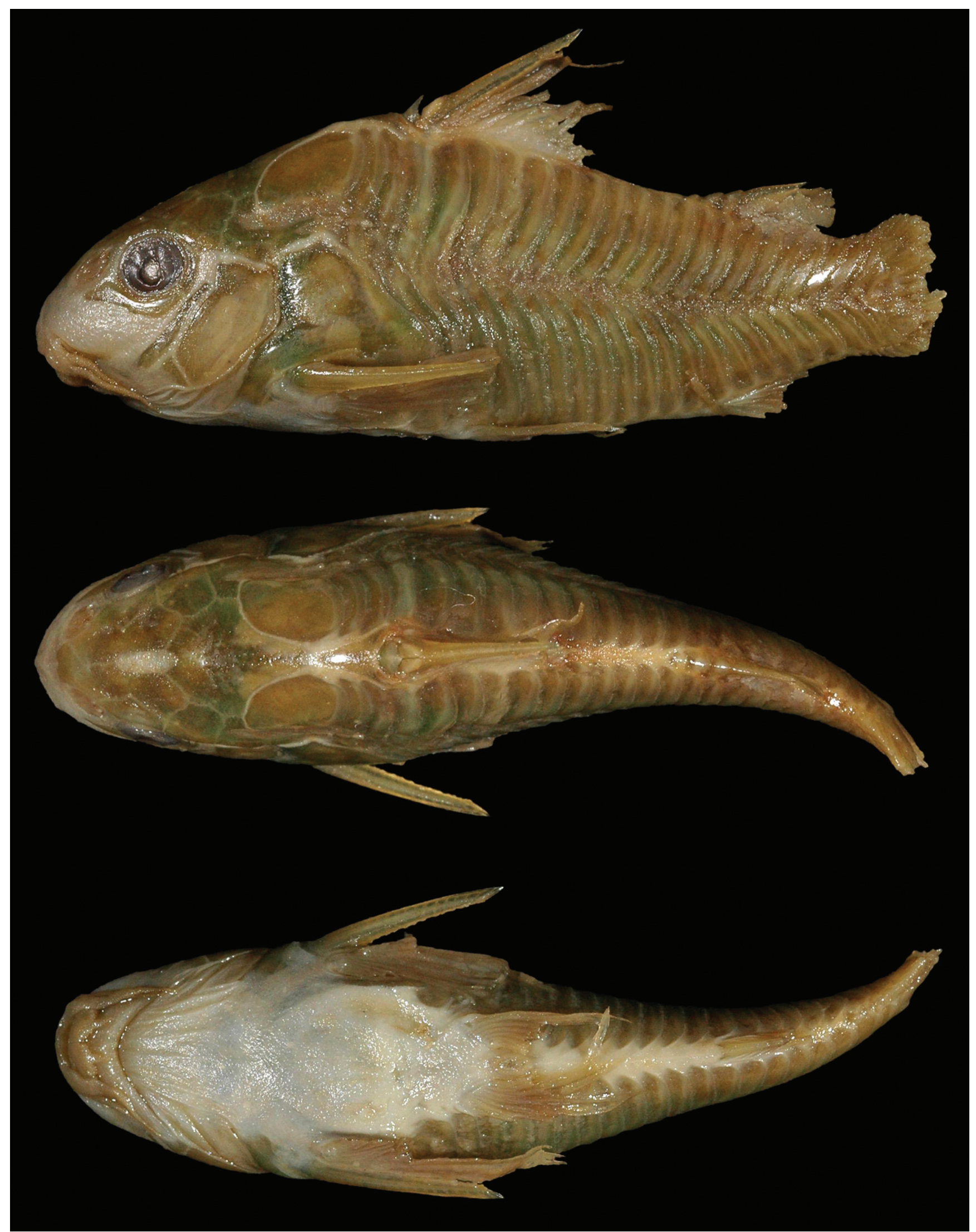

Fig. 1. Lectotype of Callichthys paleatus, BMNH 1917.7.14.18, 1, $31.0 \mathrm{~mm}$ SL, uncertain locality, collected by Charles Darwin between the years of 1832-1836. Lateral, dorsal and ventral views. Photo by Mark Allen, copyright Natural History Museum, London. 


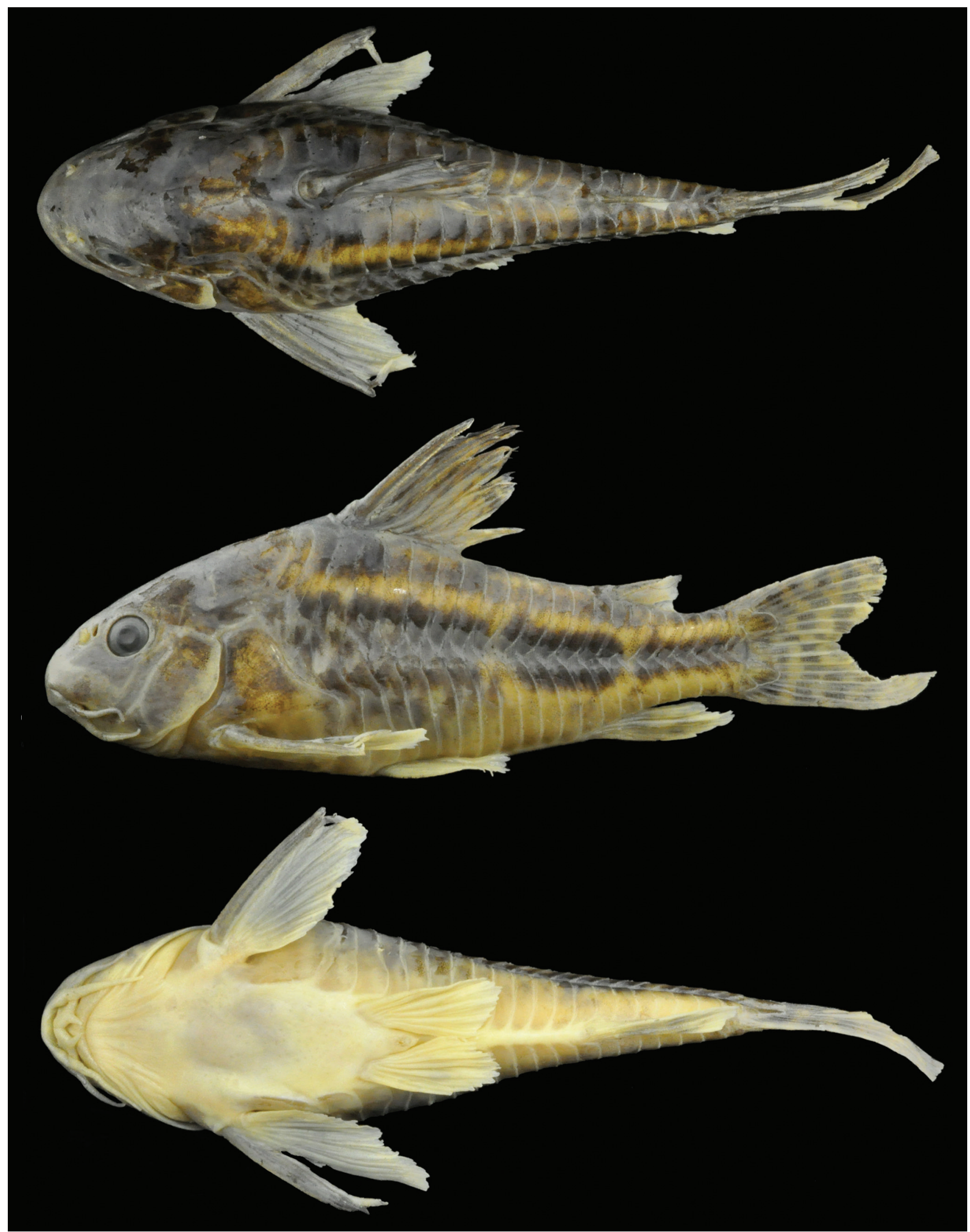

Fig. 2. Specimen of Corydoras paleatus, NRM 54230, 1, $53.5 \mathrm{~mm}$ SL, captured in córrego Sarandí, Canelones, Uruguay, near to the most plausible type-locality of $C$. paleatus, the Laguna del Diario, in Maldonado. Dorsal, lateral and ventral views. Photo by Celso Ikedo. 
Diagnosis. Corydoras paleatus can be distinguished from its congeners, with exception of C. armatus (Günther, 1868) and $C$. microcephalus, by the presence of perpendicularly directed serrations along entire posterior margin of the pectoral spines (vs. serrations directed towards pectoralspine origin; serrations directed towards pectoral-spine tip; perpendicularly directed serrations, if present, bifid or restricted to proximal region of pectoral spine); from $C$. armatus by the absence of contact between infraorbital 2 and compound pterotic (vs. presence); from C. microcephalus by the presence of a longitudinal series of three large black blotches along midline of flank (vs. four or five midline blotches in C. microcephalus). Additionally, C. paleatus can be distinguished from C. cohui Myers \& Weitzman, 1954, C. diphyes Axenrot \& Kullander, 2003, C. Alaveolus, C. froehlichi, C. gryphus Tencatt, Britto \& Pavanelli, 2014, C. habrosus, C. lacrimostigmata Tencatt, Britto \& Pavanelli, 2014, C. longipinnis Knaack, 2007 and C. lymnades Tencatt, Vera-Alcaraz, Britto \& Pavanelli, 2013 by having the anterior region of the dorsal fin black ( $v s$. with black spots or bars); from C. carlae Nijssen \& Isbrücker, 1983, C. garbei Ihering, 1911, C. difluviatilis Britto \& Castro, 2002 by the presence of hyaline or black pectoral fin (vs. with black spots or bars); from C. reynoldsi, C. tukano Britto \& Lima, 2003 and $C$. weitzmani by the absence of a conspicuous coloration pattern in the region of the eye ( $v s$. presence of a transversal black stripe across the eye); from C. gladysae, $C$. micracanthus, $C$. petracinii by having dorsal spine relatively long, with adpressed distal tip slightly surpassing the base of the last branched dorsal-ray (vs. conspicuously short, with adpressed distal tip not reaching the base of the last branched dorsal-ray; from C. ehrhardti by the presence of transversal black bars on caudal-fin lobes (vs. caudal-fin lobes hyaline or brownish); from C. steindachneri by having a fold in the middle portion of the lower lip ( $v s$. absence).

Description. Morphometric data presented in Table 1. Head compressed with slightly convex dorsal profile; triangular in dorsal view. Snout slightly pointed. Head profile convex from snout to anterior nares; roughly straight from this point to tip of posterior process of parieto-supraoccipital. Profile slightly convex along dorsal-fin base. Postdorsal-fin body profile concave to adipose-fin spine; markedly concave from this point to caudal-fin base. Ventral profile of body nearly straight from isthmus to pectoral girdle; slightly convex from this point until pelvic girdle. Profile nearly straight from pelvic girdle to base of first anal-fin ray; slightly concave until caudal-fin base. Body roughly elliptical in cross section at pectoral girdle, gradually becoming more compressed toward caudal fin.

Eye rounded, located dorso-laterally on head; orbit delimited dorsally by frontal and sphenotic, ventrally by infraorbitals. Anterior and posterior nares close to each other, only separated by flap of skin. Anterior naris tubular. Posterior naris close to anterodorsal margin of orbit, separated from it by distance equal to diameter of naris.
Mouth small, subterminal, width nearly equal to bony orbit diameter. Maxillary barbel moderate in size, not reaching anteroventral limit of gill opening. Outer mental barbel slightly longer than maxillary barbel. Inner mental barbel fleshy, base slightly separated from its counterpart. Small rounded papillae covering entire surface of all barbels, upper and lower lips, and isthmus.

Mesethmoid short; anterior tip moderately developed, smaller than $50 \%$ of bone length (see Britto, 2003: 123, character 1, state 1; fig. 1B), with very reduced lateral cornua; posterior portion widened, partially exposed and possessing minute odontodes. Nasal slender, curved laterally, anterior portion of inner margin laminar; mesial border contacting only frontal. Frontal elongated, narrow, width less than half entire length; anterior projection short, size smaller than nasal length. Frontal fontanel large, oval; posterior tip slightly entering anterior margin of parieto-supraoccipital. Parieto-supraoccipital wide, posterior process long and contacting nuchal plate; region of contact between posterior process and nuchal plate covered by thick layer skin.

Two laminar infraorbitals with minute odontodes; infraorbital 1 large, ventral laminar expansion moderately developed (Fig. 3a); anterior portion with large expansion; infraorbital 2 small, posteroventral margin contacting posterodorsal ridge of hyomandibula, dorsal tip slender, contacting only sphenotic (Fig. 3a). Posterodorsal ridge of hyomandibula close to its articulation with opercle oblong; exposed, slightly thickened and bearing small odontodes; dorsal ridge of hyomandibula between compound pterotic and opercle covered by thick layer of skin. Interopercle covered by a thin layer of skin, somewhat triangular, anterior projection well developed. Preopercle slender, elongated, minute odontodes sparse on external surface. Opercle compact, width slightly smaller than length; free margin angulated, with uncinate expansion in some specimens; without serrations and covered by small odontodes. Anteroventral portion of cleithrum exposed; Posterolateral portion of scapulocoracoid exposed; minute odontodes sparse on exposed areas. Vertebral count 21 (2), 22 (1); ribs 6 (3), first pair conspicuously large; complex vertebra compact in shape. Neural and haemal spines pointed.

Four branchiostegal rays decreasing in size posteriorly. Hypobranchial 2 somewhat triangular, tip ossified and directed towards anterior portion, posterior margin cartilaginous; ossified portion well developed, about twice size cartilaginous portion. Five ceratobranchials with expansions increasing posteriorly; ceratobranchial 1 with small process on anterior margin of mesial portion; ceratobranchial 3 notched on posterolateral margin; ceratobranchial 5 toothed on posterodorsal surface, 35 to 39 (3) teeth aligned in one row. Four epibranchials with similar size; epibranchial 2 slightly larger than others, with small pointed process on laminar expansion of posterior margin; epibranchial 3 with curved mesially uncinate process on laminar expansion of posterior margin. Two wide pharyngobranchials ( 3 and 4); pharyngobranchial 3 with large triangular process on 
posterior margin. Upper tooth plate oval; 37 to 45 (3) teeth aligned in two rows on posteroventral surface.

Lateral-line canal entering neurocranium through compound pterotic, splitting into two branches before entering sphenotic: pterotic branch with a single pore; preoperculomandibular branch conspicuously reduced, with a single pore opening close to postotic main canal. Sensory canal continuing through compound pterotic, entering sphenotic as temporal canal, which splits into two branches: one branch giving rise to infraorbital canal, other branch entering frontal through supraorbital canal. Supraorbital canal not branched, running through nasal bone. Epiphyseal pore opening at supraorbital main canal. Nasal canal with three openings, first on posterior edge, second on posterolateral portion and third on anterior edge. Infraorbital canal running through entire second infraorbital, extending to infraorbital 1 and opening into two pores. Preoperculomandibular branch giving rise to preoperculo-mandibular canal, which runs through entire preopercle with three openings, leading to pores 3,4 , and 5 , respectively.

Dorsal fin triangular, located just posterior to second dorsolateral body plate. Dorsal-fin rays II,8 (42), II,9 (3), posterior margin of dorsal-fin spine with five to nine serrations, only in distal portion of spine; serrations smoothly directed towards dorsal-spine tip; serrations absent in some specimens. Nuchal plate exposed with minute odontodes; spinelet short; spine relatively long, adpressed distal tip slightly surpassing base of last branched dorsal-ray; anterior margin with small odontodes. Pectoral fin triangular, its origin just posterior to gill opening. Pectoral-fin rays I,7 (14), I,8 (31); posterior margin of pectoral spine with 16-24 relatively well-developed serrations along its entire length; serrations disposed perpendicularly to spine (Fig. 4a). Pelvic fin oblong, located just below first ventrolateral body plate, and at vertical through first branched dorsal-fin ray. Pelvicfin rays i,5. Adipose fin roughly triangular, separated from base of last dorsal-fin ray by generally seven dorsolateral body plates. Anal fin triangular, located just posterior to $12^{\text {th }}$ ventrolateral body plate, and at vertical through anterior margin of adipose-fin spine. Anal-fin rays i,6 (42), i,7 (3). Caudal-fin rays $i, 12, i$, generally three dorsal and ventral procurrent rays, respectively; bilobed, lobes with similar size.

Two or three laterosensory canals on trunk; first ossicle tubular, second ossicle laminar and last lateral-line canal encased in third dorsolateral body plate. Body plates with minute odontodes scattered over exposed area; conspicuous line of odontodes confined on posterior margins; dorsolateral body plates 23 (15), 24 (26), 25 (4); ventrolateral body plates 20 (8), 21 (31), 22 (6); dorsolateral body plates along dorsalfin base 5 (30), 6 (15); dorsolateral body plates between adipose- and caudal-fin 6 (2), 7 (24), 8 (19), 9 (2); preadipose platelets 1 (1), 2 (18), 3 (22), 4 (4), adipose spine opposed to anal-fin insertion; small platelets covering base of caudal-fin rays; small platelets disposed dorsally and ventrally between junctions of lateral plates on posterior portion of caudal peduncle. Anterior margin of orbit with platelets above junction of frontal and lateral ethmoid. Ventral surface of trunk with few amorphous platelets.

Table 1. Morphometric data of Corydoras paleatus $(\mathrm{n}=45)$ and holotype and paratypes of Corydoras froehlichi $(\mathrm{n}=32)$. S.D. $=$ standard deviation.

\begin{tabular}{|c|c|c|c|c|c|}
\hline & \multicolumn{2}{|c|}{ Corydoras paleatus } & \multicolumn{3}{|c|}{ Corydoras froehlichi } \\
\hline & Low-High & Mean \pm S.D. & Holotype & Low-High & Mean \pm S.D. \\
\hline Standard length (mm) & $30.7-53.8$ & $42.8 \pm 5.6$ & 51.5 & $38.6-51.5$ & $44.5 \pm 2.2$ \\
\hline \multicolumn{6}{|c|}{ Percents of standard length } \\
\hline Depth of body & $32.3-40.5$ & $35.8 \pm 1.7$ & 33.2 & $31.9-36.8$ & $34.7 \pm 1.3$ \\
\hline Predorsal distance & $44.5-49.9$ & $47.1 \pm 1.3$ & 46.4 & $45.5-49.3$ & $47.1 \pm 1.0$ \\
\hline Prepelvic distance & $42.9-55.0$ & $47.3 \pm 1.9$ & 44.7 & $41.6-49.1$ & $45.4 \pm 1.4$ \\
\hline Preanal distance & $73.3-81.3$ & $78.4 \pm 1.6$ & 80.4 & $76.7-82.1$ & $79.0 \pm 1.4$ \\
\hline Preadipose distance & $80.3-85.5$ & $82.8 \pm 1.3$ & 81.0 & $73.7-82.9$ & $79.9 \pm 1.8$ \\
\hline Length of dorsal spine & $17.1-28.6$ & $23.1 \pm 2.9$ & 25.2 & $19.3-28.3$ & $24.3 \pm 2.2$ \\
\hline Length of pectoral spine & $19.5-30.1$ & $25.9 \pm 2.3$ & 23.3 & $21.4-26.7$ & $24.1 \pm 1.2$ \\
\hline Length of adipose-fin spine & $6.5-11.3$ & $8.4 \pm 1.2$ & 9.9 & $5.2-10.2$ & $8.2 \pm 1.1$ \\
\hline Depth of caudal peduncle & $10.6-14.5$ & $12.9 \pm 0.8$ & 13.6 & $11.1-15.4$ & $14.1 \pm 0.8$ \\
\hline Length of dorsal-fin base & $14.6-19.0$ & $16.7 \pm 0.9$ & 16.9 & $14.6-19.0$ & $16.7 \pm 0.9$ \\
\hline Dorsal to adipose distance & $16.9-24.4$ & $21.3 \pm 1.7$ & 19.2 & $16.5-21.4$ & $18.9 \pm 1.3$ \\
\hline Maximum cleithral width & $24.9-31.3$ & $27.1 \pm 1.3$ & 26.4 & $23.9-27.9$ & $26.0 \pm 1.1$ \\
\hline Head length & $37.8-46.7$ & $40.0 \pm 1.6$ & 39.2 & $38.3-41.5$ & $39.8 \pm 0.9$ \\
\hline Length of maxillary barbel & $8.7-22.8$ & $16.1 \pm 2.8$ & 6.0 & $4.2-14.8$ & $8.2 \pm 2.3$ \\
\hline \multicolumn{6}{|c|}{ Percents of head length } \\
\hline Head depth & $69.5-92.6$ & $83.2 \pm 3.8$ & 79.2 & $75.5-85.4$ & $79.9 \pm 2.9$ \\
\hline Least interorbital distance & $27.7-36.0$ & $33.6 \pm 1.8$ & 29.2 & $23.0-31.0$ & $28.4 \pm 1.5$ \\
\hline Horizontal orbit diameter & $16.4-24.0$ & $20.6 \pm 1.5$ & 22.8 & $20.1-26.6$ & $23.0 \pm 1.2$ \\
\hline Snout length & $28.2-35.9$ & $32.3 \pm 1.6$ & 33.2 & $31.8-38.6$ & $34.8 \pm 1.8$ \\
\hline Least internarial distance & $12.3-18.5$ & $15.7 \pm 1.4$ & 14.9 & $9.3-16.8$ & $14.5 \pm 1.3$ \\
\hline
\end{tabular}



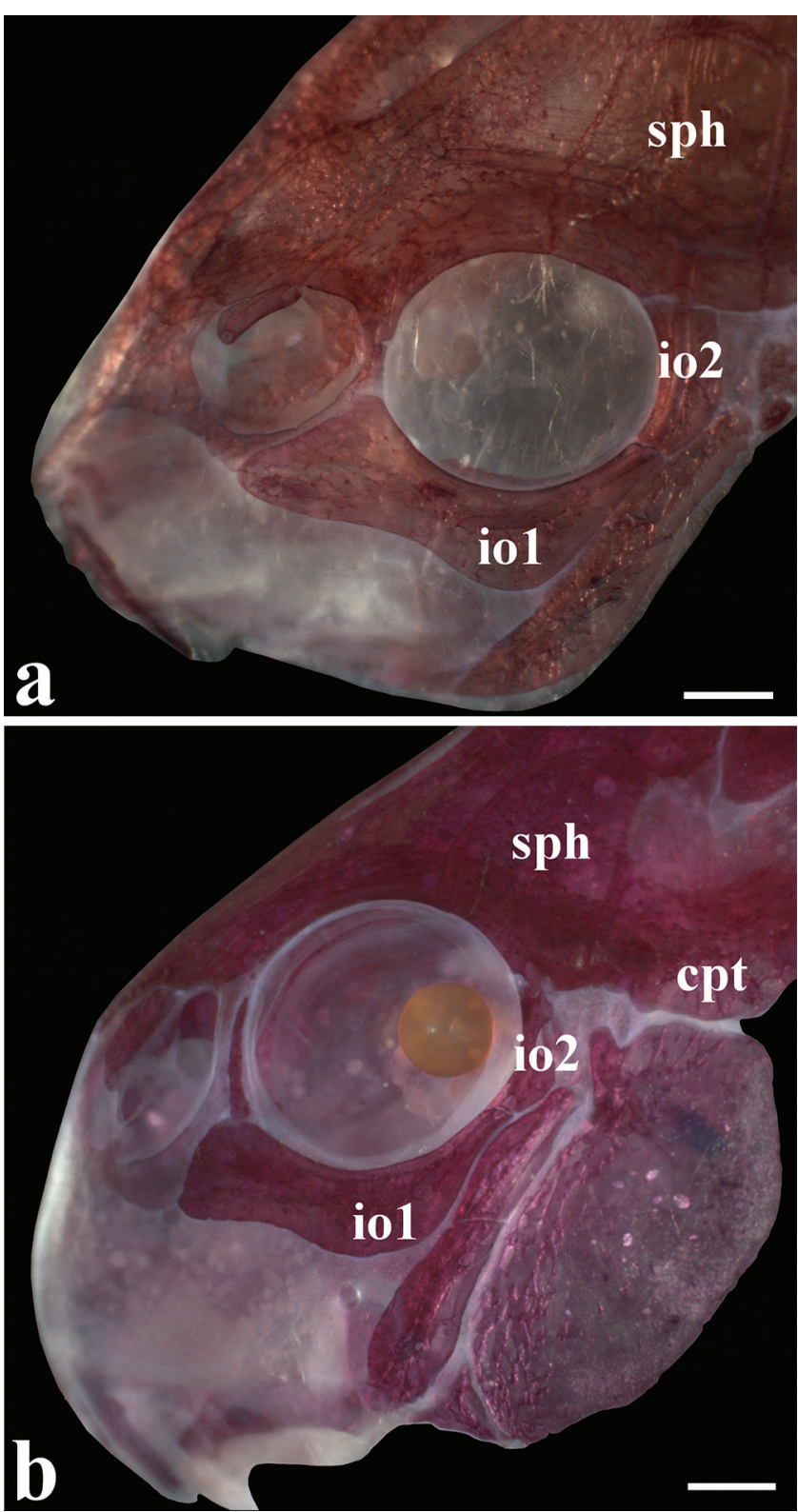

Fig. 3. Lateral view of the head of cleared-and-stained specimens of (a) Corydoras paleatus, UFRGS 1722, $37.6 \mathrm{~mm}$ SL, and (b) Corydoras froehlichi, MCP 13388, $40.2 \mathrm{~mm} \mathrm{SL}$, paratype. Abbreviations: io1: infraorbital 1, io2: infraorbital 2, sph: sphenotic, cpt: compound pterotic. Scale bar $=1.0 \mathrm{~mm}$.
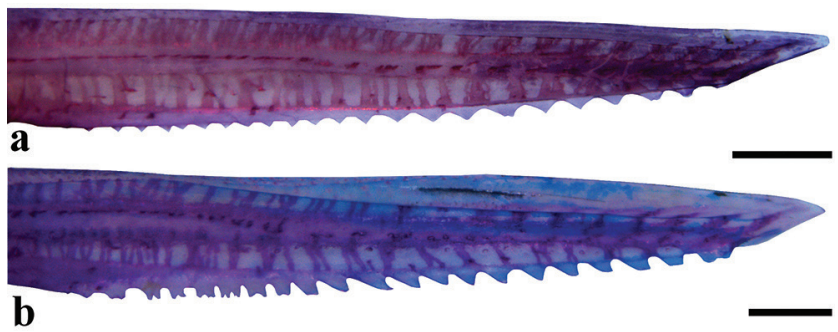

Fig. 4. Pectoral-fin spine of cleared-and-stained specimens of (a) Corydoras paleatus, UFRGS 1722, $37.6 \mathrm{~mm} \mathrm{SL}$, and (b) Corydoras froehlichi, MCP 13388, $40.2 \mathrm{~mm} \mathrm{SL}$, paratype. Scale bar $=1.0 \mathrm{~mm}$.
Color in alcohol. Ground color of body grayish yellow, with top of head black. Dark spots, when present, generally restricted to snout tip; until anterior margin of orbit in some specimens. Opercle with yellowish border; anterior portion black or dark brown. Dorsal series of four black blotches, first on anterior portion of dorsal-fin base, second on posterior portion of dorsal-fin base, third on adipose-fin base and fourth on caudal-fin base. Dorsal portion of dorsolateral body plates generally with black area; forming longitudinal dorsal stripe in some specimens. Midline of flank with longitudinal series of three large conspicuous black blotches; anterior and middle blotches generally rectangular, and posterior generally ellipsoid; blotches conspicuously elongated in some specimens; coalescent, forming thick and irregular longitudinal stripe in few specimens; fragmented blotches in some specimens. Presence of conspicuously smaller irregular black patches between midline blotches in few specimens. Ventral portion of ventrolateral body plates black in some individuals. First and second branched rays of dorsal fin, including membranes, black or dark brown, and the remaining rays mottled. Pectoral fin black with hyaline distal margin; few specimens with entirely hyaline pectoral fin. Pelvic fin black on its anterior half; entirely hyaline in some specimens. Adipose-fin membrane black or with dark brown area on distal portion. Anal fin blotched; almost entire black in some specimens. Middle portion of caudal-fin base with small black dot. Caudal fin with three to five transversal black bars; hyaline portion of caudal fin with smaller or equal width as bars.

Color in life. Similar to preserved specimens. Ground color of body yellowish orange with iridescent green coloration (Fig. 5).

Sexual dimorphism. In general, the presence of lanceolate genital papilla is useful to recognize Corydoradinae males (see Nijssen \& Isbrücker, 1980; Britto, 2003), as can be observed on Corydoras paleatus as well. Additionally, dorsal-fin spine and odontodes are more developed in males; first and second dorsal-fin branched rays slightly surpass dorsal-spine tip. Females are generally larger than males.

Geographic distribution. Corydoras paleatus is known from the lower rio Paraná basin in Argentina, coastal rivers from Southern Brazil, Rio Grande do Sul State, and Uruguay, rio de La Plata basin in Argentina and Uruguay, and rio Uruguay basin in Uruguay (Fig. 6).

Conservation status. Populations of Corydoras paleatus are known from at least three relatively wide regions, comprising territories from Argentina, Brazil and Uruguay, and no imminent threat is suspected for the species as whole, therefore, according to the International Union for Conservation of Nature (IUCN) categories and criteria (IUCN Standards and Petitions Subcommittee, 2014), C. paleatus can be classified as Least Concern (LC). 


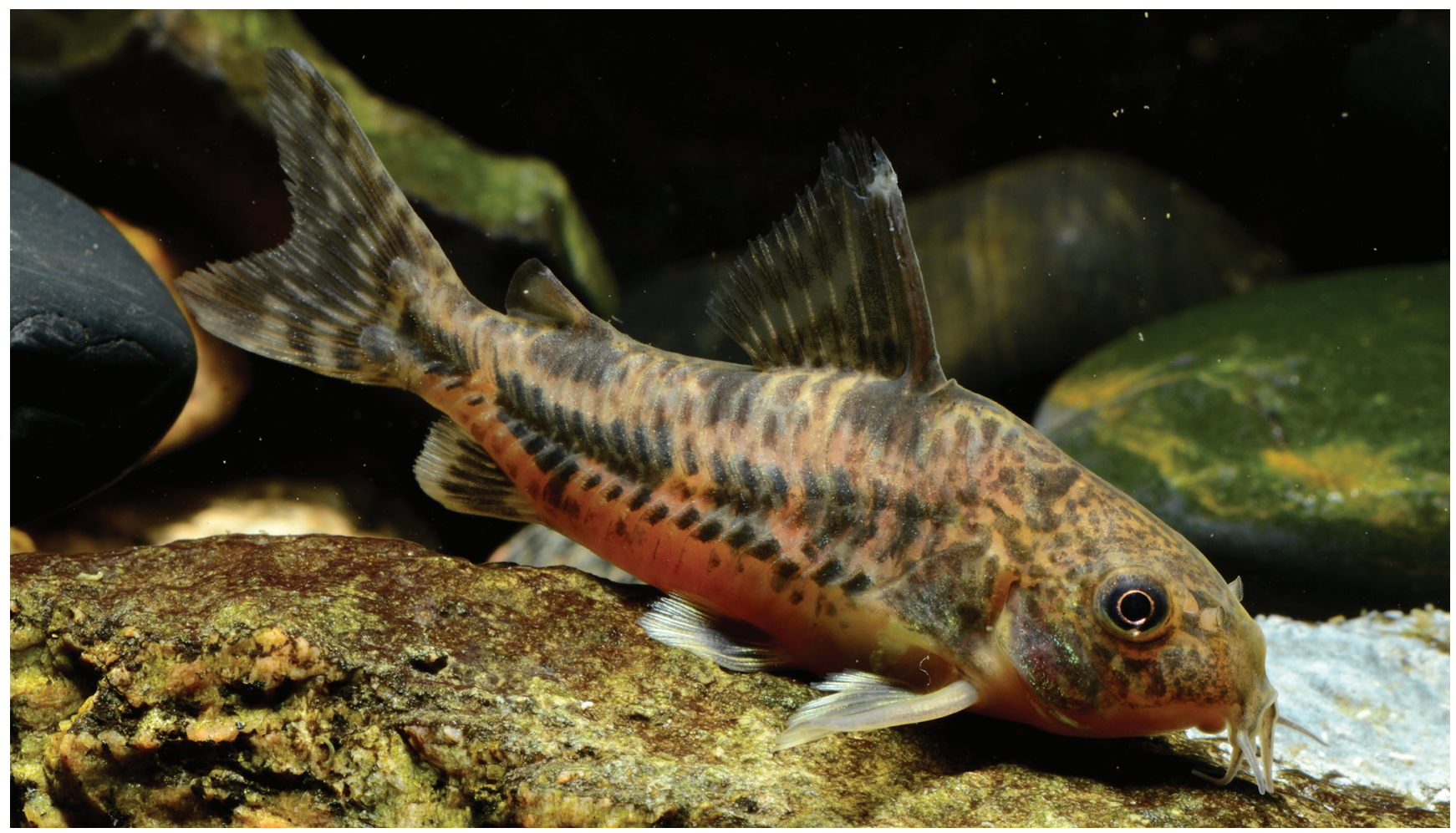

Fig. 5. Uncatalogued live specimen of Corydoras paleatus with approximately $43.0 \mathrm{~mm}$ SL, from the Laguna del Diario, Maldonado, Uruguay. Photo by Hans-Georg Evers.

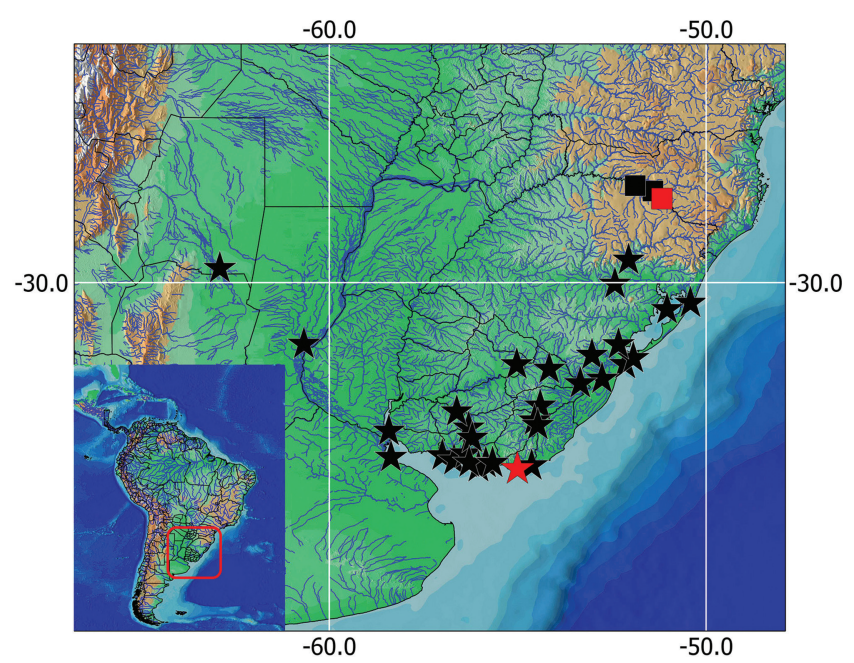

Fig. 6. Map showing the geographical distribution of Corydoras paleatus (stars) and Corydoras froehlichi (squares). The red star represents the Laguna del Diario, Maldonado, Uruguay, one of the plausible places that may be the type-locality of $C$. paleatus. The red square represents the type-locality of $C$. froehlichi, rio Pelotas, Rio Grande do Sul, Brazil. Each symbol may represent more than one locality.

Remarks. In the review of Corydoras conducted by Nijssen \& Isbrücker (1980), the authors restricted the typelocality of C. paleatus, however this was done without any justification. Despite this region has been part of the places visited by Darwin on his voyage (Darwin, 1839), there is no evidence for such a restriction of the type-locality. Unfortunately, there are no concrete evidences that lead to the exact type-locality where Darwin may have collected C. paleatus, but it is more likely that this species has been collected in Uruguay and not in Argentina. Calviño (2007) rescued the type-locality of four species collected by Darwin during the voyage of the Beagle. The author analyzed potential locations where Darwin would have collected, finding the Laguna del Diario, a lake which supplies the city of Maldonado, where Darwin stayed for more than two months and collected several fish species. Jenyns (1842) mentions that "in a lake suddenly drained" (Darwin (1839: 134) mentioned "nearly drained") many fish samples were collected, which makes sense since the fish sampling tends to be more practical in low volume sites. Corydoras paleatus inhabits the Laguna Del Diario (Calviño pers. comm.), so it is possible that it may have been collected during the draining period. However, without the original labels, it is quite risky assign or even restricts the type-locality of $C$. paleatus.

Regarding the synonymic list of Corydoras paleatus proposed by Nijssen \& Isbrücker (1980), some adjustments were proposed herein. The specimen described by Valenciennes (1840) was referred as Corydoras punctatus var. argentina in Steindachner (1879a), assigned as nomen nudum in the synonymy of $C$. marmoratus (see Nijssen \& Isbrücker, 1980: 204). After that, C. maculatus was proposed as a nomen novum for Corydoras punctatus var. argentina 
in Steindachner (1879b). Despite the fact that this specimen could not be traced (Nijssen \& Isbrücker, 1980: 204), d'Orbigny (1847) provided an illustration of it, in which it is possible to observe a slender and regular longitudinal black stripe just above midline of flank and no additional spots or blotches on the body, and also the entire distal border of dorsal fin black, being thus clearly different from the color pattern of $C$. paleatus. By this reason, both names should be removed from the synonymy of $C$. paleatus.

Additionally, based on the original description by Regan (1912) and on the analysis of the lectotype of $C$. microcephalus, it was possible to observe the presence of a longitudinal series of four to five large black blotches along midline of flank, clearly distinguishing this species from C. paleatus, which presents only three blotches. Some specimens of $C$. paleatus present fragmented midline blotches, which can also be observed in C. longipinnis (see Knaack, 2007b: 41, fig. 9), nevertheless, even this condition is clearly different from what is displayed by the lectotype of C. microcephalus (see Knaack, 2007a: 29, fig. 10). Analysis of some specimens from Argentina, Buenos Aires Province near Tres Arroyos, also revealed the presence of four to five large midline blotches. However, the material is relatively old and damaged making it difficult to accurately assign these specimens to $C$. microcephalus. Nevertheless, these specimens clearly fit more with the morphotype of C. microcephalus than of $C$. paleatus, and, by this reason, they were considered here as Corydoras cf. microcephalus. For now, the most reasonable decision is to consider $C$. microcephalus as valid and removing it from C. paleatus synonymy until further analysis be performed.
Reis (2003: 301) presented a new synonymic list for Corydoras paleatus, which includes the same species from Nijssen \& Isbrücker (1980) study plus Silurus quadricostatus and Silurus septemradiatus. Devicenzi (1925: 307), in his review of the fish species of Larrañaga from Uruguay, stated that the species described by Larrañaga (1923) were actually synonyms of $C$. paleatus. However, this statement was given without any concrete evidence, since it appears that Devicenzi (1925) only provided the original description by Larrañaga and added some comments. It is not completely clear but, apparently, he does not examine those specimens. It is also important to mention that the direct link between Larrañaga's species and $C$. paleatus is not that obvius since the brief descriptions fit for several other callichthyids and no specimens could be traced for examination, either for the Larrañaga's (1923) or the Devicenzi's (1925) works. Therefore, both species described by Larrañaga constitute species inquirendae following the definition of the Code (a species of doubtful identity needing further investigation; ICZN, 1999: 116) and also need to be removed from the synonymy of $C$. paleatus.

The inclusion of part of the material of Corydoras longipinnis in the synonymy of $C$. paleatus is justifiable due to the fact that the allotype (AI 222) clearly corresponds to $C$. paleatus. Examination of $C$. marmoratus type-series also indicated the presence of more than one species. The lectotype and some paralectotypes (Fig. 7) (NMW 467751, 46775-2, 46777-1 and 46777-2) clearly fit with the description of $C$. paleatus, and therefore, this species is kept in its synonymy. However, the paralectotype NMW 46776 corresponds to the description of $C$. longipinnis.

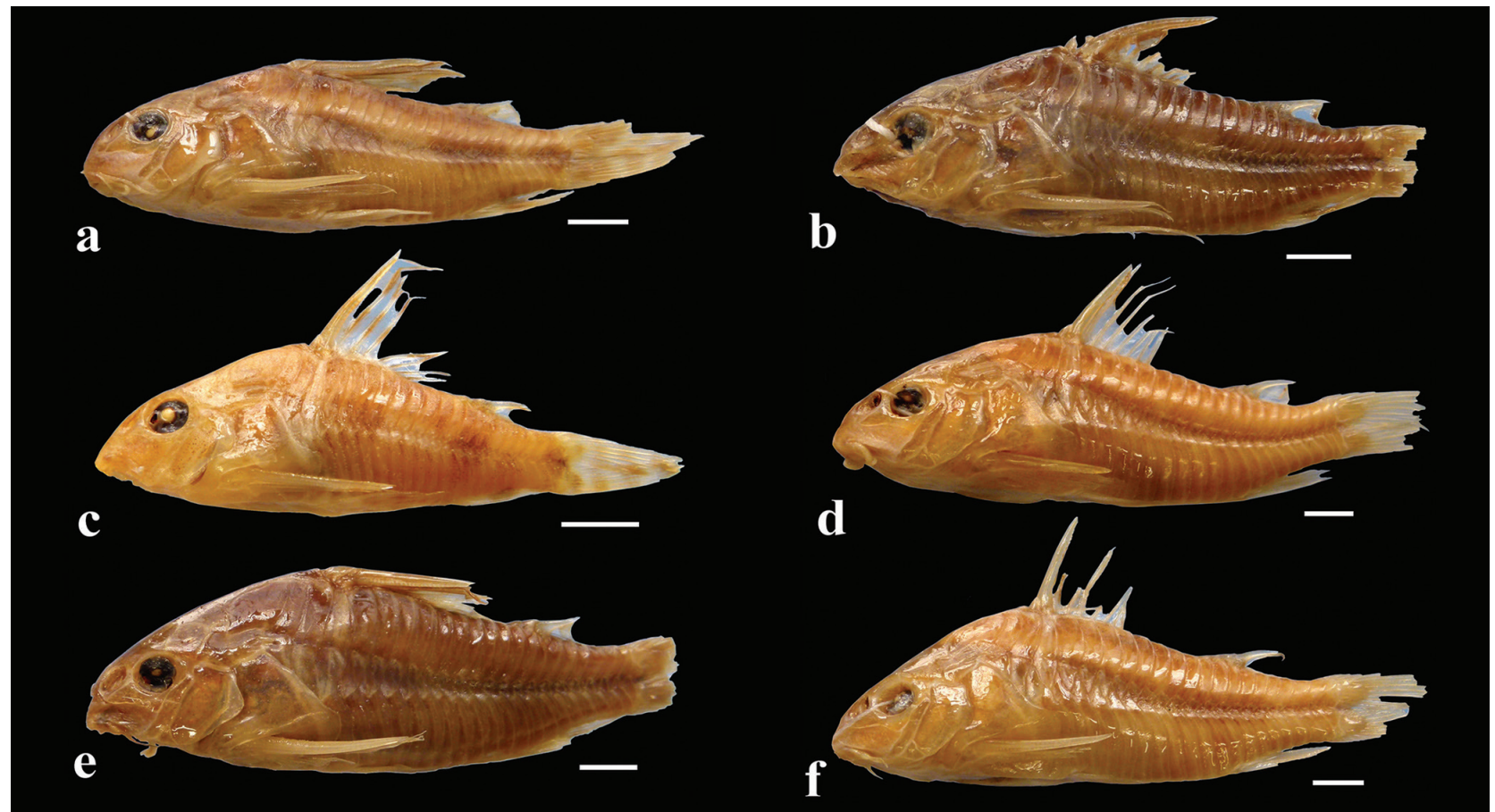

Fig. 7. Type-specimens of Corydoras marmoratus, showing (a) the lectotype, NMW 5538, and the paralectotypes (b) NMW 46775-2, (c) NMW 46776, (d) NMW 46777-1, (e) NMW 46775-1, and (f) NMW 46777-2. Scale bar=5.0 mm. Photos by Helmut Wellendorf. 
Material examined. Unknown locality: BMNH 1917.7.14.18, 1, $31.0 \mathrm{~mm}$ SL, lectotype of Callichthys paleatus designated by Nijssen \& Isbrücker, 1980, uncertain locality, 1832-1836. Argentina: Santiago Del Estero: AI 222, $54.3 \mathrm{~mm} \mathrm{SL}$, allotype of Corydoras longipinnis by original designation, rio Salí. Santa Fé: MLP 4936, 5, 40.7-53.6 mm SL, unnamed stream. Brazil: Rio Grande do Sul: MCP 14855, 1, 53.7 mm SL, Água Parada stream (about $200 \mathrm{~m}$ from the city of Maquiné). MCP 17804, 2, 35.7-42.1 mm SL, Senandes stream. MCP 18670, 4 of 18, 39.4$48.6 \mathrm{~mm} \mathrm{SL}$, stream tributary to the rio Jacuí, $1 \mathrm{~km}$ west of the BR-471, on the road Rio Pardo/Pântano Grande. MCP 21361, 10, 23.1-37.8 $\mathrm{mm}$ SL, pool adjacent to lagoa Machado. MCP 25134, 1, 40.5 mm SL, córrego Arambaré. MCP 27300, 7, 24.531.4 mm SL, córrego Candiota. MCP 38286, 4 of 6, 30.4-44.2 mm SL, córrego Arambaré. MZUSP 23173, 5, 26.7-33.6 mm SL, rio Pelotas. MZUSP 25214, 15, 19.5-35.2 mm SL, stream on the path of Caçapava farm - Estação Ecológica do Taim. MZUSP 25215, 5, 16.7-36.6 mm SL, stream on the path of Caçapava farm - Estação Ecológica do Taim. MZUSP 27039, 4, 21.9-33.8 mm SL, unnamed stream. MZUSP 43522, 1, $46.6 \mathrm{~mm} \mathrm{SL}$, córrego Água Parada. MZUSP 43577, 6, 40.2-41.7 mm SL, rio Cará. UFRGS 1721, 35, 25.2-46.7 mm SL, shallow pool watercourse from arroio Taim - Estação Ecológica do Taim. UFRGS 1722, 22, 19.2-50.7 $\mathrm{mm} \mathrm{SL}, 1 \mathrm{c} \& \mathrm{~s}, 37.6 \mathrm{~mm} \mathrm{SL}$, stream on the road of Albardão - Estação Ecológica do Taim. UFRGS 1723, 16 of 27, 28.7-39.5 mm SL, ancient main channel of the rio Taim - Estação Ecológica do Taim. UFRGS 1726, 4 of 7, 35.5-45.0 $\mathrm{mm}$ SL, parallel channel to BR 471, towards Rio Grande/Chuí Estação Ecológica do Taim. UFRGS 1728, 6, 26.4-32.0 mm SL, stream on the road of Albardão - Estação Ecológica do Taim. UFRGS 1730, 1, $41.3 \mathrm{~mm}$ SL, new channel of the córrego Taim - Estação Ecológica do Taim. UFRGS 1735, 3 of 4, 33.6-38.2 mm SL, córrego Taim - Estação Ecológica do Taim. UFRGS 4365,6 of 15, 27.6-47.4 mm SL, pool close to lagoa Rondinha. UFRGS 7612, 5 of $15,36.1-42.4 \mathrm{~mm} \mathrm{SL}$, stream tributary to the rio Camaquã. UFRGS 8387, 8 of 32, 34.0-49.8 mm SL, córrego Minuano. UFRGS 9157, 16, 32.5-47.7 mm SL, drain on Rice planting close to sanga das Oveiras. UFRGS 11539, 56 of 62 , 20.2-31.1 mm SL, Bacupari lagoon. UFRGS 12440, 4, 37.6-52.2 mm SL, rio Dom Marcos. UFRGS 13761, 15 of 43, 34.9-43.5 $\mathrm{mm}$ SL, córrego Pelotas. UFRGS 14222, 8 of 59, 31.8-47.3 mm SL, córrego Forquetinha. UFRGS 15699, 4, 31.9-52.0 mm SL, pools and adjacent areas close to Super Porto in Rio Grande. UFRGS 15707, 1, $38.5 \mathrm{~mm} \mathrm{SL}$, pools and adjacent areas close to Super Porto in Rio Grande. UFRGS 15804, 48, 19.0-50.8 $\mathrm{mm}$ SL, 2 c\&s 29.9-32.2 mm SL, channel that flows into the Atlantic. Uruguay: Canelones: NRM 39305, 1, $53.9 \mathrm{~mm}$ SL, córrego Pando. NRM 39325, 1, 40.5 mm SL, córrego Pando. NRM 54230, 1, $53.5 \mathrm{~mm}$ SL, córrego Sarandí, under bridge a Ruta 1. ZVC-P 1230, 4, 36.6-51.3 mm SL, córrego Canélon Grande, downstream of the weir. Cerro Largo: ZVC-P 7168, 2 of 3, 22.1-25.6 mm SL, Cañada Tres Boliches, Ruta 8. ZVC-P 9182, 2 of 3, 38.0-40.7 mm SL, Canal arrocero. Colonia: ZVC-P 178, 2, 29.1-34.3 $\mathrm{mm} \mathrm{SL}$, arm of the rio Uruguay. ZVC-P 8834, 4, 24.6-29.2 mm SL, rio Uruguay, Punta Gorda, in Laguna. ZVC-P 9574, 1, 35.9 mm SL, Cañada Martínez. Flores: ZVC-P 8367,
1, 30.9 mm SL, La Cordobesa stream. Florida: ZVC-P 9540, 3 of 4, 34.3-37.5 mm SL, Cañada Las Piedras. ZVC-P 10952, 3, 32.3-43.7 mm SL, Canãda Del Juncal. ZVC-P 10970, 1, 28.0 mm SL, Pintado stream. Lavalleja: ZVC-P 6779, 1, $45.3 \mathrm{~mm}$ SL, rio Cebollatí. ZVC-P 7731, 2, 16.0-46.0 mm SL, Bañados Asperezas Retamosa, Ruta 8. Maldonado: ZVC-P 3610, 2 of 3, 29.4-32.2 $\mathrm{mm} \mathrm{SL}$, in the larger water body near to temporary ponds where there was Cynolebias, nearby the Cerro Salamanca. ZVC-P 4262, 4, 24.5-44.2 mm SL, Laguna Escondida, vicinity of José Ignacio. Montevideo: ZVC-P 209, 10, 43.1-60.7 mm SL, Camino Melilla first stream after the airport. ZVC-P 927, 1, $34.4 \mathrm{~mm}$ SL, Lagunas de Carrasco. ZVC-P 4837, 1, 24.4 mm SL, Lagunas de Carrasco. ZVC-P 4941, 8, 32.0-48.1 mm SL, Carrasco. ZVC-P 5061, 3, 32.4-38.2 mm SL, Bañados de Carrasco. Paysandu: UFRGS 7784, 1, $24.7 \mathrm{~mm}$ SL, Carpinchuri stream on the rout 3, between the cities of Salto and Paysandu. Rivera: UFRGS 7320, 1, $41.6 \mathrm{~mm}$ SL, Batovi stream on the rout 27, at km 24. San José: ZVC-P 215, 4, 32.9-44.2 mm SL, Paso Del Arroyo Mauricio. ZVC-P 230, 1, 27.1 mm SL, Sauce stream. ZVC-P 8900, 2, 19.820.0 mm SL, Arazatí, Humendal. Soriano: MZUSP 45698, 1, $33.3 \mathrm{~mm}$ SL, rio Uruguay. Tacuarembó: NRM 54316, 4 of 6, 23.4-27.8 mm SL, Caraguatá stream. Treinta y Tres: ZVC-P 381, 4, 26.4-29.9 mm SL, Ruta 18, path to Arrozal Santa Ana, bordering the rio Tacuarí (5.1 km from Arrozal). NRM 54174, 5 of 17, 25.6-26.9 $\mathrm{mm} \mathrm{SL}$, rio Olimar.

\section{Corydoras froehlichi, new species}

urn:1sid:zoobank.org:act:5C878AD9-653C-4556-8EAC9D56455E5F93

\section{(Figs. 3b, 4b, 8, 9; Table 1)}

Holotype. MCP 48433, $51.5 \mathrm{~mm}$ SL, Brazil, Rio Grande do Sul, Esmeralda, rio Pelotas, 2747'51'S 51¹0'17'W, 11 Dec 1988, E. H. L. Pereira, L. Bergmann, P. Azevedo \& R. E. Reis.

Paratypes. All from Brazil, upper rio Uruguai basin. Rio Grande do Sul: MCP 19354, 6, 26.9-36.5 mm SL, rio Uruguai, Barracão, 27³6'22"S 51²7'40”W, 13 Nov 1996, E. Pereira, J. Silva \& R. Reis. MCP 19368, 5, 41.4-44.5 mm SL, rio Pelotas, Esmeralda, 2747'51'S 51¹0'42"W, 12 Nov 1996, J. Pezzi \& E. Pereira. MCP 12945, 18, 39.7$45.6 \mathrm{~mm}$ SL, 2 c\&s, 38.3-43.1 mm SL; MNRJ 44488, 4, 43.0-45.6 mm SL; MZUSP 118698, 4, 43.3-47.9 mm SL; NUP 17733, 4, 47.0-48.8 mm SL; collected with holotype. Santa Catarina: MCP 12362, 8, 33.6-44.6 mm SL, rio Canoas, Tupitinga, 27³5'11'S 51²4'09'W, 9 Sep 1988, A. Ramires, A. Bergmann, P. Azevedo \& E. Pereira. MCP 12782, 3, 42.6-44.0 mm SL, rio Canoas, Tupitinga, 27³5'11'S 51²4'09'W, 10 Nov 1988, C. Lucena, E. Pereira, P. Azevedo \& A. Ramires. MCP 13388, 9, 36.7$46.2 \mathrm{~mm}$ SL, $1 \mathrm{c} \& \mathrm{~s}, 40.2 \mathrm{~mm} \mathrm{SL}$, rio do Peixe, Concórdia, 2727'55.11'S 51'53'8.55'W, 16 Feb 1989, R. Reis, E. Pereira, L. Bergmann \& P. Azevedo. 


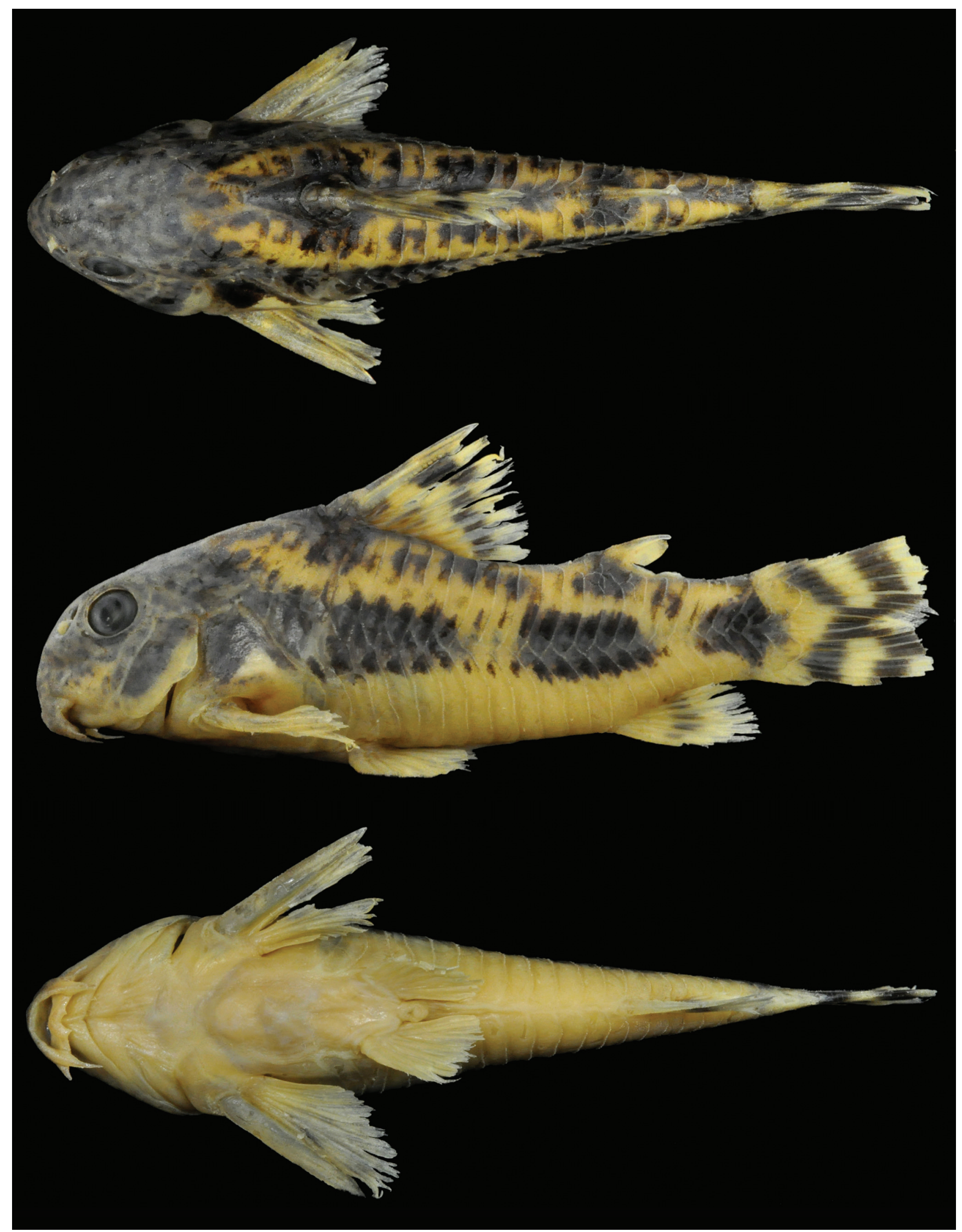

Fig. 8. Holotype of Corydoras froehlichi, MCP 48433, $51.5 \mathrm{~mm}$ SL, Brazil, Rio Grande do Sul State, Esmeralda, rio Pelotas, upper rio Uruguai basin. Dorsal, lateral and ventral views. 
Diagnosis. Corydoras froehlichi can be distinguished from its congeners, with exception of C. aurofrenatus, C. carlae, C. cochui, C. difluviatilis, C. diphyes, C. ehrhardti, C. ellisae Gosline, 1940, C. flaveolus, C. garbei, C. gladysae, C. gryphus, C. habrosus, C. lacrimostigmata, C. longipinnis, C. lymnades, C. micracanthus, C. microcephalus, C. orcesi, C. paleatus, C. petracinii, C. reynoldsi, C. septentrionalis Gosline, 1940, C. steindachneri, C. tukano and C. weitzmani by having a longitudinal series of relatively large black blotches, with size similar or larger than the size of orbit, on midline of flank (vs. midline of flank with a longitudinal series of small black blotches, with size conspicuously smaller than the size of orbit, in C. agassizii, C. ambiacus Cope, 1872, C. araguaiaensis Sands, 1990, C. breei, C. copei, C. cruziensis, C. haraldschultzi, C. incolicana Burgess, 1993, C. isbrueckeri, C. lamberti, C. noelkempffi, C. ornatus, C. orphnopterus, C. paucerna, C. punctatus, C. robineae Burgess, 1983, C. robustus, C. spectabilis, C. sterbai Knaack, 1962 and C. xinguensis; midline of flank lacking a distinct longitudinal series of blotches in the remaining species). The new species can be distinguished from C. aurofrenatus, C. carlae, C. cochui, $C$. diphyes, C. ehrhardti, C. ellisae, C. flaveolus, C. garbei, C. gladysae, C. gryphus, C. lacrimostigmata, C. longipinnis, C. lymnades, C. micracanthus, C. microcephalus, C. orcesi, C. paleatus, C. petracinii, C. reynoldsi, C. septentrionalis, C. steindachneri, C. tukano and C. weitzmani by the presence of striated black spots from the snout tip to nuchal plate region, forming a somewhat marbled pattern ( $v s$. spots, when present, conspicuously rounded or irregular, not forming a marbled pattern); from $C$. difluviatilis by the presence of contact between the tip of the process of the parieto-supraoccipital and nuchal plate (vs. absence); from $C$. habrosus by the presence of conspicuously thick transversal black bars on caudal-fin lobes (vs. conspicuously slender). Additionally, C. froehlichi can be distinguished from its most similar congeners, C. carlae, C. ehrhardti, $C$. longipinnis and $C$. paleatus, by the absence of small plates on the ventral surface of the trunk (vs. presence); and by having markedly rounded snout (vs. relatively pointed snout).

Description. Morphometric data presented in Table 1. Head compressed with slightly convex dorsal profile; triangular in dorsal view. Snout roughly rounded. Head profile convex from snout to tip of posterior process of parieto-supraoccipital. Profile slightly convex along dorsalfin base. Postdorsal-fin body profile concave to adiposefin spine; markedly concave from this point to caudal-fin base. Ventral profile of body nearly straight from isthmus to pectoral girdle; slightly convex from this point until pelvic girdle. Profile nearly straight from pelvic girdle to base of first anal-fin ray; slightly concave until caudal-fin base. Body roughly elliptical in cross section at pectoral girdle, gradually becoming more compressed toward caudal fin.

Eye rounded, located dorso-laterally on head; orbit delimited dorsally by frontal and sphenotic, ventrally by infraorbitals. Anterior and posterior nares close to each other, only separated by flap of skin. Anterior naris tubular. Posterior naris close to anterodorsal margin of orbit, separated from it by distance equal to diameter of naris. Mouth small, subterminal, width nearly equal to bony orbit diameter. Maxillary barbel short, not reaching anteroventral limit of gill opening. Outer mental barbel slightly longer than maxillary barbel. Inner mental barbel fleshy, base slightly separated from its counterpart; insertion of barbel in middle of lower lip. Small rounded papillae covering entire surface of all barbels, upper and lower lips, and isthmus.

Mesethmoid short; anterior tip moderately developed, smaller than 50\% of bone length (see Britto, 2003: 123, character 1, state 1; fig. 1B), with small lateral cornua; posterior portion widened, partially exposed and possessing minute odontodes. Nasal slender, curved laterally; inner margin laminar, outer margin laminar in some specimens; mesial border contacting mesethmoid and frontal. Frontal elongated, narrow, width less than half entire length; anterior projection short, size smaller than nasal length. Frontal fontanel large, oval; posterior tip extension slightly entering anterior margin of parieto-supraoccipital. Parietosupraoccipital wide, posterior process long and contacting nuchal plate; region of contact between posterior process and nuchal plate covered by thick layer skin.

Two laminar infraorbitals with minute odontodes; infraorbital 1 large, ventral laminar expansion moderately developed (Fig. 3b); anterior portion with moderately developed expansion; infraorbital 2 small, posteroventral margin contacting posterodorsal ridge of hyomandibula, dorsal tip slender, contacting only sphenotic (Fig. 3b). Posterodorsal ridge of hyomandibula close to its articulation with opercle oblong; exposed, slightly thickened and bearing small odontodes; dorsal ridge of hyomandibula between compound pterotic and opercle covered by a thick layer of skin. Interopercle covered by thick layer of skin, somewhat triangular, anterior projection well developed. Preopercle slender, elongated, minute odontodes sparse on external surface. Opercle dorso-ventrally elongated, width equal or smaller than half of its length; free margin rounded, not angulated; few specimens with smooth uncinate expansion; covered by small odontodes. Anteroventral portion of cleithrum exposed; Posterolateral portion of scapulocoracoid exposed; minute odontodes sparse on exposed areas. Vertebral count 22 (3); ribs 6 (3), first pair conspicuously large; complex vertebra compact in shape. Neural and haemal spines with distal portion expanded.

Four branchiostegal rays decreasing in size posteriorly. Hypobranchial 2 somewhat triangular, tip ossified and directed towards anterior portion, posterior margin cartilaginous; ossified portion well developed, about twice size cartilaginous portion. Five ceratobranchials with expansions increasing posteriorly; ceratobranchial 1 with small process on anterior margin of mesial portion; ceratobranchial 3 notched on posterolateral margin; ceratobranchial 5 toothed on posterodorsal surface, 30 to 37 (3) teeth aligned in one 
row. Four epibranchials with similar size; epibranchial 2 slightly larger than others, with small pointed process on laminar expansion of posterior margin; epibranchial 3 with curved mesially uncinate process on laminar expansion of posterior margin. Two wide pharyngobranchials (3 and 4), pharyngobranchial 3 with large triangular process on posterior margin. Upper tooth plate oval; 38 to 42 (3) teeth aligned in two rows on posteroventral surface.

Lateral-line canal entering neurocranium through compound pterotic, splitting into two branches before entering sphenotic: pterotic branch with a single pore; preoperculomandibular branch conspicuously reduced, with a single pore opening close to postotic main canal. Sensory canal continuing through compound pterotic, entering sphenotic as temporal canal, which splits into two branches: one branch giving rise to infraorbital canal, other branch entering frontal through supraorbital canal. Supraorbital canal not branched, running through nasal bone. Epiphyseal pore opening at supraorbital main canal. Nasal canal with three openings, first on posterior edge, second on posterolateral portion and third on anterior edge. Infraorbital canal running through entire second infraorbital, extending to infraorbital 1 and opening into two pores. Preoperculomandibular branch giving rise to preoperculo-mandibular canal, which runs through entire preopercle with three openings, leading to pores 3,4 , and 5 , respectively.

Dorsal fin roughly triangular, located just posterior to second dorsolateral body plate. Dorsal-fin rays II,7 (1), II, $8^{*}$ (31), posterior margin of dorsal-fin spine with 17 to 18 serrations along entire posterior margin of spine; serrations directed towards dorsal-spine tip; nuchal plate exposed with minute odontodes; spinelet short; spine relatively long, adpressed distal tip slightly surpassing base of last branched dorsal-ray, anterior margin with small odontodes. Pectoral fin triangular, its origin just posterior to gill opening. Pectoral-fin rays I,8; posterior margin of pectoral spine with 20-22 well developed serrations along its entire length; serrations directed towards pectoral-spine tip; presence of bifid perpendicularly directed serrations on proximal region of spine (Fig. 4b). Pelvic fin oblong or rounded, located just below first ventrolateral body plate, and at vertical through first branched dorsal-fin ray. Pelvicfin rays i,5. Adipose fin roughly triangular, separated from base of last dorsal-fin ray by generally six dorsolateral body plates. Anal fin triangular, located just posterior to $12^{\text {th }}$ ventrolateral body plate, and at vertical through anterior margin of adipose-fin spine. Anal-fin rays i,6. Caudal-fin rays $i, 12, i$, generally four dorsal and ventral procurrent rays; bilobed, lobes with similar size.

Three laterosensory canals on trunk; first ossicle tubular, second ossicle laminar and last lateral-line canal encased in third dorsolateral body plate. Body plates with minute odontodes scattered over exposed area, a conspicuous line of odontodes confined on posterior margins; dorsolateral body plates 23 (11), 24* (21); ventrolateral body plates 20 (4), 21 (21), 22* (7); dorsolateral body plates along dorsal- fin base $5^{*}(12), 6$ (20); dorsolateral body plates between adipose- and caudal-fin 7 (9), 8* (23); preadipose platelets 2 (9), $3^{*}(20), 4$ (3), adipose spine opposed to anal-fin insertion; small platelets covering base of caudal-fin rays; small platelets disposed dorsally and ventrally between junctions of lateral plates on posterior portion of caudal peduncle. Anterior margin of orbit with platelets, above posterior portion of lateral ethmoid and above junction of frontal and lateral ethmoid; in some specimens ventral margin of nasal capsule, above mesethmoid, with platelets. Ventral surface of trunk without platelets.

Color in alcohol. Ground color of body yellowish, with top of head black. Presence of striated black spots from tip of snout to nuchal plate region. Opercle with yellowish border; anterior portion dark brown. Dorsal series of four black blotches, first on anterior portion of dorsalfin base, second on posterior portion of dorsal-fin base, third on adipose-fin base and fourth on caudal-fin base. Dorsal portion of dorsolateral plates generally with dark chromatophores scarcely scattered. Midline of flank with longitudinal series of three large black blotches; anterior and middle blotches conspicuously rectangular; posterior ellipsoid. Dorsal fin generally with transversal black bar on its middle portion. Pectoral fin with diffuse spots; hyaline in some specimens. Pelvic fin generally hyaline; with black spots in few specimens. Adipose fin hyaline; with black area on distal portion of membrane in some specimens. Anal fin with transversal black bar; hyaline in some specimens. Middle portion of caudal-fin base with small black dot. Caudal fin with generally three transversal black bars; hyaline portion of caudal fin with same width as bars; transversal bars conspicuously larger in width.

Sexual dimorphism. Male specimens of Corydoras froehlichi also present lanceolate genital papilla (see Nijssen \& Isbrücker, 1980; Britto, 2003). As C. paleatus, males of the new species also present dorsal-fin spine and odontodes more developed than females, and first and second dorsal-fin branched rays slightly surpassing dorsal-spine tip. Females are generally larger than males. In addition, presence of elongated pelvic fin in males (Fig. 9a); females with shorter and rounded pelvic fin (Fig. 9b). The rounded pelvic fin of the females is used to make a ventral pouch to hold the eggs during spawning (H. Evers, pers. comm.).

Distribution. Corydoras froehlichi is known from the upper rio Uruguai basin, from the rivers Canoas, do Peixe and Pelotas (Fig. 6).

Etymology. Corydoras froehlichi is named in honor and memory of Dr. Otávio Froehlich (1958-2015), UFMS (Universidade Federal de Mato Grosso do Sul), great teacher, mentor and dear friend, for generously sharing his knowledge with several colleagues, besides contributing to the development of LFCT as researcher and person. 


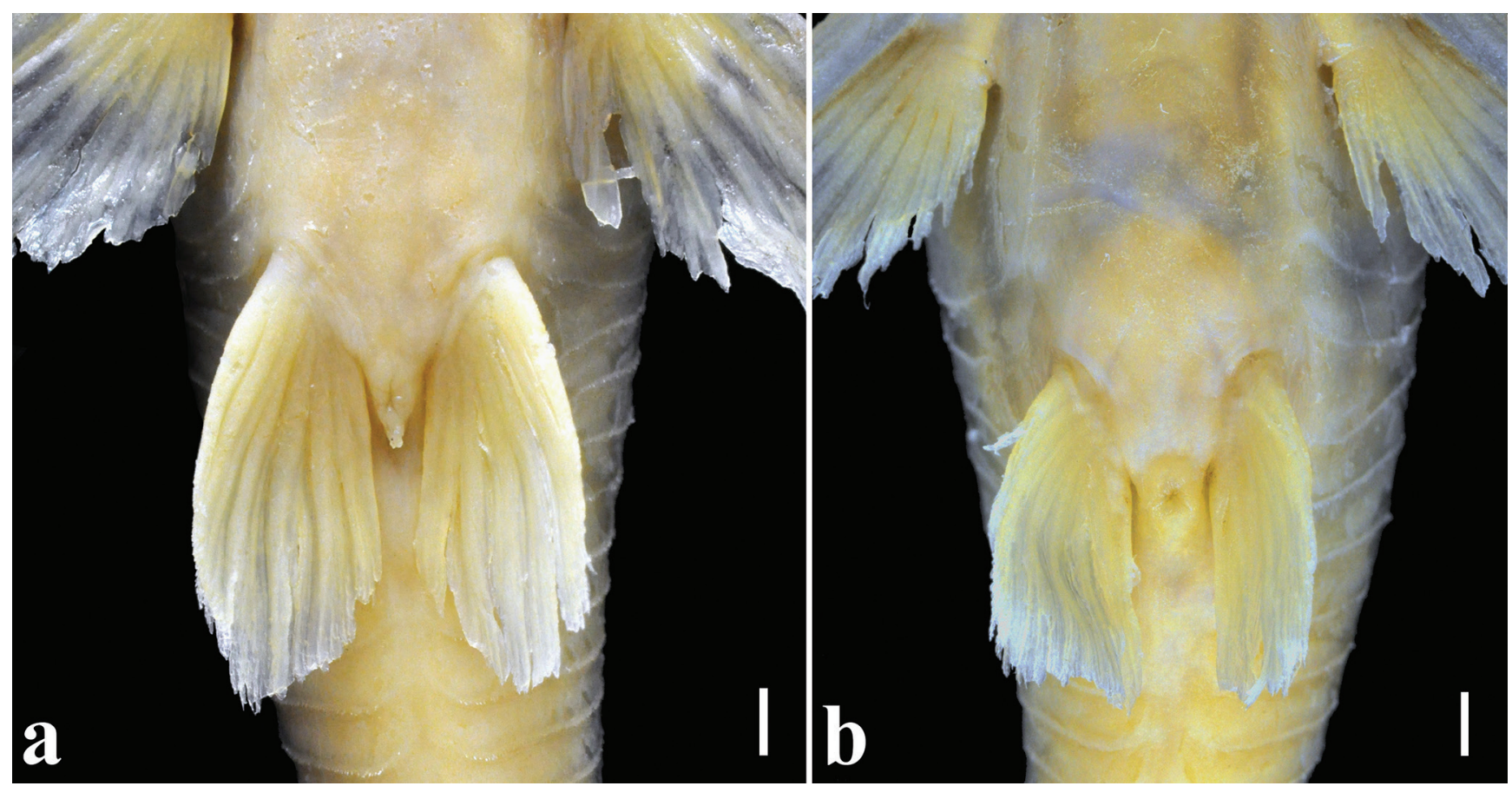

Fig. 9. Sexual dimorphism in Corydoras froehlichi, showing (a) the slender and more elongated pelvic fin on males, MCP 12945, $42.4 \mathrm{~mm} \mathrm{SL}$, paratype, and (b) the shorter and rounded pelvic fin on females, MCP 12945, $44.4 \mathrm{~mm}$ SL, paratype. Scale bar $=1.0 \mathrm{~mm}$.

Conservation status. Despite Corydoras froehlichi is known only from the rio Pelotas and two of its tributaries, Canoas and do Peixe rivers, it is probably widespread in other tributaries to the rio Pelotas. Additionally, no imminent threat is suspected, therefore, according to the International Union for Conservation of Nature (IUCN) categories and criteria (IUCN Standards and Petitions Subcommittee, 2014), C. froehlichi can be classified as Least Concern (LC).

\section{Discussion}

After the original description of C. paleatus, various changes occurred on its taxonomy. Explanations for such a set of changes could be related to misconceptions about its diagnosis and description, and also the absence of accurate information about the type-locality. Additionally, the geographic distribution of the populations erroneously identified as C. paleatus is relatively wide, occurring in almost entire Southern region of South America, which made the taxonomic problems related to this species even worse.

Even with the unsolved question regarding C. paleatus type-locality, Jenyns (1842: 113) mentioned that the color pattern of pectoral, pelvic and anal fins of C. paleatus were "almost wholly dusky", which was essential for its clear recognition. With the exception of C. microcephalus, the color patterns of the aforementioned fins, plus dorsal fin, can be very useful to distinguish C. paleatus from its most similar congeners, such as C. carlae, C. ehrhardti,
C. froehlichi and C. longipinnis (see Diagnosis). On the other hand, C. froehlichi can be promptly distinguished from its most similar congeners, C. carlae, C. ehrhardti, C. longipinnis, C. microcephalus and C. paleatus, by the presence of striated black spots from the snout tip to nuchal plate region, forming a somewhat marbled pattern in some specimens ( $v s$. spots, when present, rounded, not forming marbled pattern) and thicker transversal black bars on caudal fin ( $v s$. bars, when present, slender).

Despite the presence of multiples cases of convergent color pattern in Corydoras (see Alexandrou et al., 2011), some phylogenetic hypotheses (e.g. Alexandrou et al., 2011; Vera-Alcaraz, 2013) suggest that many species sharing similar color pattern with $C$. paleatus may constitute a monophyletic grouping. In Alexandrou et al. (2011) phylogenetic study, C. paleatus appeared in a relatively small clade comprised by $C$. albolineatus, $C$. diphyes, $C$. ehrhardti, C. flaveolus, C. longipinnis, C. nattereri, C. potaroensis, C. reynoldsi and C. tukano. Vera-Alcaraz (2013) presented a comprehensive phylogenetic hypothesis based on morphological and molecular data, proposing a 'C. paleatus clade', which includes C. cochui, C. diphyes, C. ehrhardti, C. flaveolus, C. longipinnis, C. nattereri and $C$. tukano. Among the aforementioned species, only C. albolineatus, $C$. nattereri and $C$. potaroensis does not share similar color pattern with C. paleatus. Tencatt et al. (2013) also found a similar result with the inclusion of C. lymnades in Britto's (2003) data matrix, finding it as a sister-group of $C$. flaveolus, and both close related to $C$. paleatus. Since the general color pattern displayed by $C$. 
paleatus and most of its close-related species seems to be shared, it is quite possible that $C$. froehlichi could also be close related to the aforementioned species.

Corydoras longipinnis is the species most often misidentified as C. paleatus. Knaack (2007b) considered specimens with the same color pattern of $C$. paleatus as females of $C$. longipinnis, and, by this reason, specimens with black pectoral fins from the rio Dulce drainage (Fig. 10) are frequently misidentified as females of C. longipinnis. Additionally, data presented by Knaack (2007b) do not fit with the type-material analyzed herein, such as the number of dorsolateral body plates, stated ranging from 20 to 21 in the description, and from 22 to 23 here. Therefore, the morphotypes from the upper rio Paraná, rio Uruguai and coastal rivers of southern Brazil and Uruguay basins correspond to $C$. longipinnis. However, the scarcity of available material of $C$. longipinnis topotypes made it difficult to clearly identify this species and to conclude that those morphotypes are certainly from that species. With the exception of the holotype, allotype, and five paratypes, the remaining type material is in the private collection of Knaack, who recently passed away (Zarske, 2013), and therefore the location of this material, about 60 specimens, is currently uncertain. In addition to the holotype and allotype, four topotypes could be examined here.

In the original description of $C$. longipinnis, Knaack (2007b) mentioned that one of the main diagnostic features of the species is the elongation of the first and second branched dorsal-fin rays in males of $C$. longipinnis. Some specimens from the rio Uruguai, rio Tibagi, coastal rivers of southern Brazil and Uruguay and mainly rio Iguaçu basins (see Baumgartner et al., 2012: 116), all misidentified as $C$. paleatus, also present this feature, but it occurred variably and, apparently, is not related to the size of the specimen, since large males may lack this elongation. Despite the similarity in the morphology and color pattern with the holotype, the diagnostic morphological features pointed by Knaack (2007b) overlap with the examined populations and many other similar species, like C. carlae, C. ehrhardti and even C. paleatus. By this reason, these populations were treated here as $C$. longipinnis until more material of this species, especially from the lower rio Paraná, can be examined for a possible future redescription and improvement of its geographical distribution.

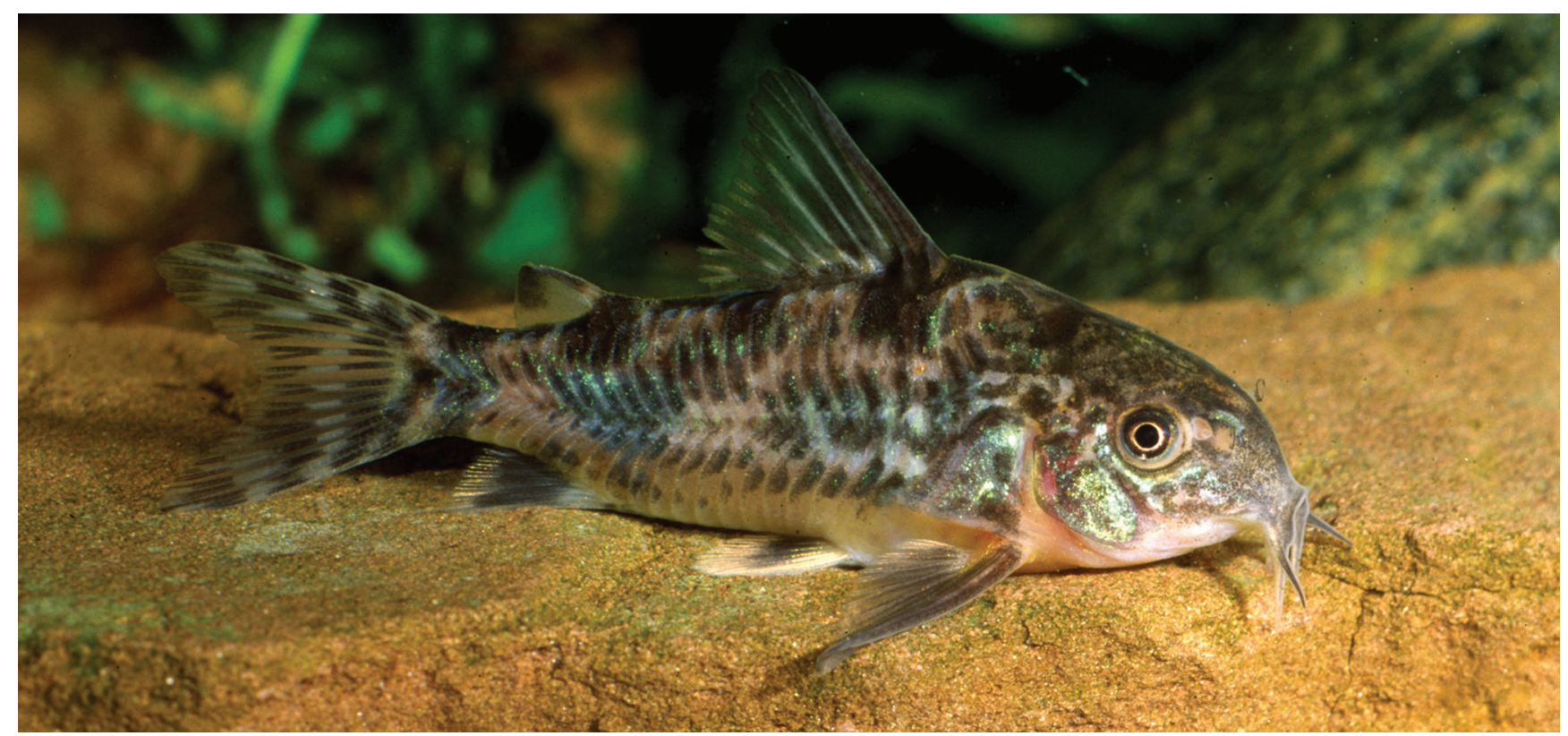

Fig. 10. Uncatalogued live specimen of Corydoras paleatus, with approximately $46.0 \mathrm{~mm}$ SL, from the rio Dulce basin, Entre Rios, Argentina. Photo by Hans-Georg Evers.

Comparative material examined. All lots of the comparative material available in Britto (2003) were analyzed. In addition, the following specimens were examined: Corydoras acutus: Peru: Unknown department: MNRJ 3985, 2, 47.1-54.8 mm SL, SanshoCaño. Corydoras adolfoi: Brazil: Amazonas: MZUSP 26641, 1, $32.5 \mathrm{~mm}$ SL, holotype of $C$. adolfoi Burgess, 1982, tributary to the upper rio Negro. Corydoras ambiacus: Peru: Loreto: MCP 26178, 1, 42.5 mm SL, rio Pacaya; MCP 26209, 10 of 19, 25.0-33.3 mm SL, Caño Yarina. Ucayali. MZUSP 26053, 2, 41.8-47.2 mm SL, Iamiriacocha. Corydoras approuaguensis Nijssen \& Isbrücker,
1983: French Guyana: Cayenne: MZUSP 27895-6, 2, 43.0-46.1 $\mathrm{mm} \mathrm{SL}$, paratypes of $C$. approuaguensis rio Approuague. Corydoras araguaiaensis: Brazil: Mato Grosso: MZUSP 87155, 4 of 33, 24.9-46.7 mm SL, 2 c\&s, 27.6-31.8 mm SL, Corixo da Saudade. Corydoras areio: Brazil: Mato Grosso do Sul: ZUFMSPIS 1314, 15, 34.4-41.9 mm SL, 2 c\&s, 38.1-38.5 mm SL, Periquito stream. Corydoras armatus: Brazil: Amazonas: MZUSP 49567, 1, $45.3 \mathrm{~mm}$ SL, rio Acre. Corydoras aurofrenatus: Paraguay: Concepción: NRM 23529, 10 of 33, 31.4-45.7 mm SL, Arroyo Laguna Penayo where it crosses the road Concepción-Paso Barreto. 
Corydoras bifasciatus: Brazil: Pará: MZUSP 38976, 16, paratypes, 23.6-30.0 mm SL, creek at left bank of the rio Cururu. Corydoras blochi Nijssen, 1971: Brazil: Roraima: MZUSP 8580, 3, 31.0-42.6 mm SL, paratypes of $C$. blochi, Igarapé on Fazenda Canadá, tributary to the rio Uraricoera. Corydoras bondi: Guyana: BarimaWaini: ROM 66202, 7 of 134, 33.8-39.9 mm SL, 3 c\&s of 134, 36.7$38.6 \mathrm{~mm}$ SL, Waikerebi Creek. Corydoras brevirostris: Venezuela: Bolívar: LBP 3080, 10, 23.8-27.7 mm SL, 3 c\&s, 25.8-27.9 mm SL, Río Orinoco. Corydoras britskii: Brazil: Mato Grosso do Sul: ZUFMS-PIS 862, 12, 72.0-78.0 mm SL, marginal lagoon to rio Vermelho. Corydoras carlae: Brazil: Paraná: NUP 711, 1, 47.9 mm SL, rio Tormenta; NUP 4425, 1 c\&s, 45.0 mm SL, rio Tormenta. Corydoras cochui: Brazil: Goiás: MZUSP 89055, 6, 18.7-23.6 mm SL, rio do Peixe II. Tocantins: MZUSP 35838, 4 of 6, 16.1-18.5 mm SL, rio Javaés. Corydoras condiscipulus: French Guyana: Cayenne: MZUSP 38957, 7, 34.1-40.3 mm SL, paratypes of $C$. condiscipulus Nijssen \& Isbrücker, 1980, Cumuri Creek. Corydoras coppenamensis: Suriname: Saramacca: MZUSP 13995-99, 5, 28.2$34.9 \mathrm{~mm}$ SL, paratypes of C. bondi coppenamensis Nijssen, 1970, rio Coppename. Corydoras crimmeni: Brazil: Uncertain state: MZUSP 52490, 1, $36.1 \mathrm{~mm}$ SL, holotype of C. crimmeni Grant, 1998, aquarium specimens said to be from near the town of Boa Vista, Roraima, possibly from the rio Branco. Corydoras davidsandsi: Brazil: Amazonas: MZUSP 110066, 4 of 40, 36.041.9 mm SL, 2 c\&s of 40, 40.9-42.1 mm SL, rio Inambú. Corydoras difluviatilis: Brazil: São Paulo: MZUSP 75268, 1, 39.8 mm SL, holotype of $C$. difluviatilis Britto \& Castro, 2002, Paulicéia stream. Corydoras diphyes: Paraguay: Alto Paraná: ANSP 169756, 2, 40.7-43.1 mm SL, drainage ditches north of $\mathrm{km} 250$ (2 km east of Juan E. O'Leary on route 7). Corydoras ehrhardti: Brazil: Paraná: NUP 11255, 15, 36.5-46.8 mm SL, rio São Pedro. Corydoras elegans: Peru: Ucayali: MZUSP 26017, 6, 25.9-28.3 mm SL, Lobococha. Corydoras ephippifer: Brazil: Amapá: MZUSP 31605 , 2, 44.9-49.1 mm SL, rio Cupixi. Corydoras eques: Brazil: Amazonas: MCZ 8204, 4 of 12, 37.6-44.4 mm SL, paratypes of $C$. eques Steindachner, 1876, rio Amazonas at Codajás. Corydoras flaveolus: Brazil: São Paulo: MZUSP 424, 1, 33.4 mm SL, holotype of C. flaveolus Ihering, 1911, tributaries to the rio Piracicaba. Corydoras fowleri: Peru: Loreto: LBP 12462, 9, 44.3-59.9 mm SL, $1 \mathrm{c \& s}, 50.4 \mathrm{~mm}$ SL, tributary to the rio Ampiyacu. Corydoras garbei: Brazil: Minas Gerais: MNRJ 18089, 14, 19.2-25.3 mm SL, 2 c\&s, 25.9-27.4 mm SL, Perta-Pé lagoon. Corydoras geoffroy: Suriname: Marowijne: MZUSP 38984, 2, 38.7-45.2 mm SL, paratypes of C. octocirrus Nijssen, 1970, fall in the rio Oelamari. Corydoras gossei: Brazil: Rondônia: MZUSP 38977, 6, 48.4-53.4 mm SL, paratypes of C. gossei Nijssen, 1972, Igarapé do 13, tributary to the rio Mamoré. Corydoras griseus: Guyana: PotaroSiparuni: MZUSP 108896, 4 of 13, 31.5-36.2 mm SL, 2 c\&s of 13, 30.6-34.5 mm SL, Igarapé tributary to the rio Kuribrong. Corydoras guapore: Brazil: Mato Grosso: ZUFMS-PIS 4000, 5, 26.9-33.6 mm SL, 2 c\&s, 28.8-29.2 mm SL, rio Guaporé. Corydoras gryphus: Brazil: Paraná: MNRJ 40770, 1, $32.3 \mathrm{~mm}$ SL, holotype of $C$. gryphus Tencatt, Britto \& Pavanelli, 2014, rio Paraná (near Ponte da Amizade). NUP 14676, $3 \mathrm{c \& s}, 27.7-32.4 \mathrm{~mm} \mathrm{SL}$, paratypes of $C$. gryphus Tencatt, Britto \& Pavanelli, 2014, rio Paraná (near Ponte da Amizade). Corydoras hastatus: Brazil: Mato Grosso: NUP 6862,
116, 13.1-20.7 mm SL, baía Caiçara. Corydoras incolicana: Brazil: Amazonas: MZUSP 45717, 1, $47.6 \mathrm{~mm}$ SL, holotype of C. incolicana Burgess, 1993, rio Içana. Corydoras julii: Brazil: Piauí: NUP 16225, 1, $46.8 \mathrm{~mm}$ SL, rio Atalaia. Corydoras kanei: Brazil: Uncertain state: MZUSP 52489, 1, $36.6 \mathrm{~mm}$ SL, holotype of $C$. kanei Grant, 1998, aquarium specimens said to be from near the town of Boa Vista, Roraima, possibly from the rio Branco. Corydoras lacrimostigmata: Brazil: Paraná: MNRJ 40725, 1, 31.8 $\mathrm{mm}$ SL, holotype of C. lacrimostigmata Tencatt, Britto \& Pavanelli, 2014, rio Maria Flora; NUP 14657, 3 c\&s, 30.9-34.5 mm SL paratypes of C. lacrimostigmata Tencatt, Britto \& Pavanelli, 2014, rio Nestor. Corydoras longipinnis: Argentina: Santiago del Estero: AI 221, 1, 59.5 mm SL, holotype of C. longipinnis Knaack, 2007, río Sali. Tucumán: NUP 14440, 2 c\&s, 29.9-33.4 mm SL, Pampa-Mayo stream. Corydoras cf. longipinnis: Brazil: MCP 28974, 45, 52.3$64.8 \mathrm{~mm}$ SL, 2 c\&s, 53.6-55.1 mm SL, rio dos Sinos; NUP 12809, 10, 50.7-57.0 mm SL, Salto Santiago reservoir; NUP 12649, 6, 57.1$61.4 \mathrm{~mm}$ SL, rio Tibagi; UFRGS 5320, 10, 31.4-36.6 mm SL, rio Ibicuí Mirim. Corydoras cf. longipinnis: Uruguay: MCP 10007, 89, 18.9-43.8 mm SL, 2 c\&s, 30.6-32.1 mm SL, lagoon tributary to the rio Negro; NRM 54174, 12, 21.2-28.4 mm SL, rio Olimar; ZVC-P 1111, 1, 44.9 mm SL, Sierra Mahoma. Corydoras lymnades: Brazil: Minas Gerais: MNRJ 15765, 6, 15.8-17.7 mm SL, 2 c\&s, 18.1-18.4 mm SL, rio Peruaçu; MNRJ 40186, 1, 29.7 mm SL, holotype of C. lymnades Tencatt, Vera-Alcaraz, Britto \& Pavanelli, 2013, rio Guarda-Mor. Corydoras maculifer: Brazil: Tocantins: NUP 8970, 2, 42.0-46.0 mm SL, ribeirão Xambioazinho. Corydoras melanistius: Guyana: Unknown region: BMNH 1864.1.21.86, 1, $35.0 \mathrm{~mm}$ SL, lectotype of C. melanistius Regan, 1912, designated by Nijssen \& Isbrücker, 1967, rio Essequibo. Corydoras melini: Brazil: Amazonas: MZUSP 81163, 2, 37.0-45.0 mm SL, rio Tiquié. Corydoras cf. microcephalus: Argentina: Buenos Aires: MLP 3147, 47, 28.0-44.0 mm SL, Tres Arroyos. Corydoras multimaculatus: Brazil: Minas Gerais: MCP 29025, 2, 20.1-25.4 $\mathrm{mm}$ SL, rio Peruaçu. Corydoras napoensis: Peru: Loreto: MZUSP 26341, 1, $27.8 \mathrm{~mm}$ SL, paratype of C. napoensis Nijssen \& Isbrücker, 1986, Moronacocha. Corydoras nattereri: Brazil: São Paulo: MZUSP 110255, 4 of 31, 32.0-32.8 mm SL, 2 c\&s of 31, 32.3-34.4 $\mathrm{mm}$ SL, rio Paraitinga. Corydoras panda: Peru: Huánuco: ROM 55815, 6, 26.5-39.7 mm SL, unknown stream somewhere above Panguana in Llullapichis drainage. Corydoras pantanalensis: Brazil: Mato Grosso: NUP 10188, 1 c\&s, 46.4 mm SL, Baía Sinhá Mariana. Mato Grosso do Sul. NUP 12593, 21, 38.7-51.2 mm SL, tributary to the rio Miranda. Corydoras parallelus: Brazil: Amazonas: MZUSP 45716, 1, $47.4 \mathrm{~mm} \mathrm{SL}$, holotype of C. parallelus Burgess, 1993, rio Içana. Corydoras pinheiroi: Brazil: Rondônia: MZUSP 48099, 1, $54.3 \mathrm{~mm} \mathrm{SL}$, holotype of C. pinheiroi Dinkelmeyer, 1995, stream tributary to the rio Ribeiro, at GuajaráMirim. Corydoras potaroensis: Guyana: Potaro-Siparuni: ROM 61526, 3 of 15, 35.0-44.8 mm SL, 2 c\&s of 15, 32.6-35.1 mm SL, rio Potaro. Corydoras pygmaeus: Peru: Loreto: MZUSP 26344, 4, 13.5-20.0 mm SL, Moronacocha. Corydoras reticulatus: Peru: Ucayali: MZUSP 28752, 3, 37.3-45.1 mm SL, Iamiriacocha masisea. Corydoras robineae: Brazil: Amazonas: MZUSP 27175, 1, 33.7 mm SL, holotype of $C$. robineae Burgess, 1983, rio Aiuana. Corydoras sarareensis: Brazil: Mato Grosso: MZUSP 48100, 1, 
$40.9 \mathrm{~mm}$ SL, holotype of C. sarareensis Dinkelmeyer, 1995, rio Sararé. Corydoras septentrionalis: Venezuela: Apure: MZUSP 27953, 12, 28.7-41.9 mm SL, Caño Caiçara. Corydoras seussi: Brazil: Rondônia: MZUSP 49323, 10, 44.3-54.0 mm SL, paratypes of C. seussi Dinkelmeyer, 1996, small stream tributary to the rio Pacas-Novos (= Pacaás Novos), near Guajará-Mirim. Corydoras similis: Brazil: Acre: LBP 10648, 7, 21.4-34.3 mm SL, rio Iquiri. Corydoras splendens: Brazil: Goiás: NUP 12990, 1, 43.7 mm SL, tributary to the rio Araguaia. Mato Grosso. NUP 10195, 1 c\&s, 54.6 mm SL, Pai Caetano lake. Corydoras stenocephalus: Brazil: Amazonas: MNRJ 3625, 3, 31.2-62.3 mm SL, rio Javari. Corydoras sterbai: Brazil: Mato Grosso: MZUSP 94998, 1, 39.9 mm SL, rio Guaporé. Corydoras treitlii: Brazil: Maranhão: NUP 16224, 3, 21.5-45.6 mm SL, rio Medonho. Corydoras trilineatus: Brazil: Acre: MZUSP 30857, 3 of 25, 40.9-44.1 mm SL, 2 c\&s of 25, 44.2$43.8 \mathrm{~mm}$ SL, rio Tarauacá. Corydoras tukano: Brazil: Amazonas: MZUSP 82100, $40.9 \mathrm{~mm}$ SL, holotype of C. tukano Britto \& Lima, 2003, rio Tiquié. Corydoras xinguensis: Brazil: Mato Grosso: MZUSP 38987, 1, 34.5 mm SL, paratype of C. xinguensis Nijssen, 1972, Igarapé upstream Porori village. Corydoras zygatus: Brazil. Acre: MZUSP 30858, 4 of 15, 41.7-47.3 mm SL, rio Tarauacá.

\section{Acknowledgements}

The Núcleo de Pesquisas em Limnologia, Ictiologia e Aquicultura (Nupélia) of the Universidade Estadual de Maringá provided logistical support. The authors are grateful to Carlos Lucena (MCP), Oscar Shibatta (MZUEL), Mário de Pinna, Aléssio Datovo and Osvaldo Oyakawa (MZUSP), Cláudio Oliveira (LBP), Luiz Malabarba (UFRGS) and Otávio Froehlich (in memorian) (ZUFMS-PIS) for hosting museum visits and loaning of material. We also thank Marcelo Loureiro (ZVC-P), Vinícius Abilhoa (MHNCI), Sven Kullander (NRM), Juan Mirande (Fundación Miguel Lillo), Jorge Casciotta and Adriana Almirón (AI), Hernán López-Fernández, Don Stacey and Erling Holm (ROM), and Hugo López, Amalia Miquelarena and Diego Nadalin (MLP) for the loaning and/or donation of several specimens analyzed in this paper. For taking and sending photographs we thank Hans Evers and Felipe Cantera for C. paleatus from many localities, Helmut Wellendorf for the $C$. marmoratus type-material, Pablo Calviño for C. paleatus from the laguna Del Diario and Guillermo Terán for $C$. longipinnis topotypes. To James Maclaine and Mark Allen for the photograph of the lectotype of C. paleatus. Carlos Lucena and Héctor VeraAlcaraz (MCP), Luiz Malabarba, Juliano Ferrer and Juliana Wingert (UFRGS), Cláudio Oliveira, Ricardo Britzke, Fábio Roxo and Gabriel Silva (LBP), William Ohara, Vinicius Espíndola and Túlio Teixeira (MZUSP), Oscar Shibatta (MZUEL), Andressa Oliveira, Francisco Severo and Thomaz Sinani (ZUFMS-PIS) for gently welcome LFCT during museum visits. Weferson Graça and Pablo Lehmann for critically reading this manuscript. To Robert 'Rob' McLure for the pleasant late-night talks on Corydoras and for kindly reviewing the English language of this paper. To Fernando Paiva and Lucas Blanco by permitting the use and by the assistance in the image capture laboratory of the Universidade Federal de Mato Grosso do Sul. The Coordenação de Aperfeiçoamento de Pessoal de Nível Superior (CAPES) provided fellowships to LFCT and the Conselho Nacional de Desenvolvimento Científico e Tecnológico $(\mathrm{CNPq})$ provided grants to CSP and MRB. The Fundação Carlos Chagas Filho de Amparo a Pesquisa do Estado do Rio de Janeiro (FAPERJ) provided grants to MRB. MRB and CSP are members of the US National Science Foundation project entitled Planetary Biodiversity Inventory: All Catfish Species Inventory (ACSI). This work is part of LFCT M.Sc. dissertation.

\section{References}

Alexandrou, M. A., C. Oliveira, M. Maillard, R. A. R. McGill, J. Newton, S. Creer \& M. I. Taylor. 2011. Competition and phylogeny determine community structure in Müllerian comimics. Nature, 469: 84-89.

Aquino, A. E. \& S. A. Schaefer. 2002. The temporal region of the cranium of loricarioid catfishes (Teleostei: Siluriformes): morphological diversity and phylogenetic significance. Zoologischer Anzeiger, 241: 223-244.

Arratia, G. \& M. Gayet. 1995. Sensory canals and related bones of tertiary siluriform crania from Bolivia and North America and comparison with recent forms. Journal of Vertebrate Paleontology, 15: 482-505.

Axenrot, T. E. \& S. O. Kullander. 2003. Corydoras diphyes (Siluriformes: Callichthyidae) and Otocinclus mimulus (Siluriformes: Loricariidae), two new species of catfishes from Paraguay, a case of mimetic association. Ichthyological Exploration of Freshwaters, 14: 249-272.

Baumgartner, G., C. S. Pavanelli, D. Baumgartner, A. G. Bifi, T. Debona \& V. A. Frana. 2012. Peixes do Baixo Rio Iguaçu. Maringá, Eduem, 203p.

Bloch, M. E. 1794. Naturgeschichte der ausländischen Fische, vol. 8. Berlin. iv +174 p., pls. 361- 396 .

Britto, M. R. 2002. Análise filogenética da ordem Siluriformes com ênfase nas relações da superfamília Loricarioidea (Teleostei: Ostariophysi). Unpublished Ph. D. Thesis, Universidade de São Paulo, São Paulo.

Britto, M. R. 2003. Phylogeny of the subfamily Corydoradinae Hoedeman, 1952 (Siluriformes: Callichthyidae), with a definition of its genera. Proceedings of the Academy of Natural Sciences of Philadelphia, 153: 119-154.

Britto, M. R. \& R. M. C. Castro. 2002. New corydoradine catfish (Siluriformes: Callichthyidae) from the upper Paraná and São Francisco: the sister group of Brochis and most of Corydoras species. Copeia, 2002: 1006-1015.

Britto, M. R. \& F. C. T. Lima. 2003. Corydoras tukano, a new species of corydoradine catfish from the rio Tiquié, upper rio Negro basin, Brazil (Ostariophysi: Siluriformes: Callichthyidae). Neotropical Ichthyology, 1: 83-91.

Britto, M. R. \& R. E. Reis. 2005. A new Scleromystax species (Siluriformes: Callichthyidae) from coastal rivers of Southern Brazil. Neotropical Ichthyology, 3: 481-488.

Burgess, W. E. 1983. Corydoras robineae, a new species of callichthyid catfish from Brazil. Tropical Fish Hobbyist, 31: 42-43.

Burgess, W. E. 1993. Three new species of catfishes of the genus Corydoras (Callichthyidae: Siluriformes). Tropical Fish Hobbyist, 41: 152-158. 
Calviño, P. A. 2007. Precisión sobre la localidad tipo de cuatro especies de peces de aguas continentales colectadas por Charles Darwin, en Maldonado, Uruguay. Boletín del Killi Club Argentino, BIBKCA, 13: 40-51.

Calviño, P. A. \& F. Alonso. 2009. Two new species of the genus Corydoras (Ostariophysi: Siluriformes: Callichthyidae) from Northwestern Argentina, and redescription of C. micracanthus Regan, 1912. Revista del Museo Argentino de Ciencias Naturales, 11: 199-214.

Cazenave, J., D. A. Wunderlin, M. A. Bistoni, M. V. Amé, E. Krause, S. Pflugmacher \& C. Wiegand. 2005. Uptake, tissue distribution and accumulation of microcystin-RR in Corydoras paleatus, Jenynsia multidentata and Odontesthes bonariensis. A field and laboratory study. Aquatic Toxicology, 75: 178-190.

Cazenave, J., M. A. Bistoni, S. F. Pesce \& D. A. Wunderlin. 2006. Differential detoxification and antioxidant response in diverse organs of Corydoras paleatus experimentally exposed to microcystin-RR. Aquatic Toxicology, 76: 1-12.

Cope, E. D. 1872. On the fishes of the Ambyiacu river. Proceedings of the Academy of Natural Sciences of Philadelphia, 23: 250294, pls. 3-16.

Darwin, C. 1839. The voyage of the Beagle. London, J. M. Dent \& Sons.

Devicenzi, G. J. 1925. El primer ensayo sobre Ictiología del Uruguay. La classe "Peces" de la Zoología de don Dámaso A. Larrañaga. Anales del Museo Nacional de Montevideo, 2: 295-323.

Eigenmann, C. H. \& R. S. Eigenmann. 1890. A revision of the South American Nematognathi or cat-fishes. Occasional Papers of the California Academy of Sciences, 1: 1-508.

Eschmeyer, W. N., R. Fricke \& R. van der Laan (eds.). 2015. Catalog of fishes: genera, species, references. Availabe from: http://researcharchive.calacademy.org/research/ichthyology/ catalog/fishcatmain.asp (Date of access - 19 May 2015).

Fanta, E., F. S. Rios, S. Romão, A. C. C. Vianna \& S. Freiberger. 2003. Histopathology of the fish Corydoras paleatus contaminated with sublethal levels of organophosphorus in water and food. Ecotoxicology and Environmental Safety, 54: 119-130.

Gosline, W. A. 1940. A revision of the Neotropical catfishes of the family Callichthyidae. Stanford Ichthyological Bulletin, 2: $1-29$.

Günther, A. 1868. Diagnoses of some new freshwater fishes from Surinam and Brazil, in the collection of the British Museum. Annals and Magazine of Natural History, 1: 475-481.

Huysentruyt, F. \& D. Adriaens. 2005. Descriptive osteology of Corydoras aeneus (Siluriformes: Callichthyidae). Cybium, 29: 261-273.

International Commission on Zoological Nomenclature [ICZN]. 1999. International Code of Zoological Nomenclature [the Code]. Fourth edition. London, The International Trust for Zoological Nomenclature, c/o Natural History Museum.

Ihering, R. 1911. Algumas espécies novas de peixes d'água doce (Nematognatha) (Corydoras, Plecostomus, Hemipsilichthys). Revista do Museu Paulista, 8: 380-404.

Isbrücker, I. J. H. 2001. Catalogue of genera and species of Corydoradinae Hoedeman, 1952 (Teleostei, Ostariophysi, Callichthyidae), including type localities, type specimens, and etymology. Pp. 213-247. In: Fuller, I. A. M. Breeding Corydoradine Catfishes. Kidderminster, Ian Fuller Enteprises.

Isbrücker, I. J. H. \& H. Nijssen. 1973. Two new species of the callichthyid catfish genus Corydoras from Brazil (Pisces, Siluriformes, Callichthyidae). Beaufortia, 21: 1-7.
Isbrücker, I. J. H. \& H. Nijssen. 1992. Corydoras breei, a new species of callichthyid catfish from the Corantijn River basin in Surinam (Pisces, Siluriformes, Callichthyidae). Beaufortia, 43: 9-14.

Jenyns, L. 1842. Part IV. Fish. In: Darwin, C. R. The Zoology of the voyage of H. M. S. Beagle, under the command of Captain Fitzroy, R.N. during the years 1832 to 1836 . London: Smith, Elder, and Co.

Kaatz, I. M. \& P. S. Lobel. 1999. Acoustic behavior and reproduction in five species of Corydoras catfishes (Callichthyidae). The Biological Bulletin, 197: 241-242.

Knaack, J. 1962. Zwei neue Panzerwelse, Corydoras haraldschultzi und Corydoras sterbai (Pisces, Teleostei, Calichthyidae). Senckenbergiana Biologica, 43: 129-135.

Knaack, J. 2000. Eine weitere neue Art der Gattung Corydoras Lacépède, 1803 aus dem Mato Grosso (Pisces, Siluriformes, Callichthyidae). VDA-aktuell, 2000: 74-79.

Knaack, J. 2003. Ein weiterer neuer Panzerwels aus Bolivien: Corydoras cruziensis n. sp. (Pisces, Siluriformes, Callichthyidae). VDA-aktuell, 2003: 60-69.

Knaack, J. 2004. Beschreibung von sechs neuen Arten der Gattung Corydoras La Cépède, 1803 (Teleostei: Siluriformes: Callichthyidae). Zoologische Abhandlungen, 54: 55-105.

Knaack, J. 2007a. Beiträge zur Kenntnis der Callichthyidae (Teleostei: Siluriformes). II. Das Typusmaterial von Corydoras paleatus (Jenyns, 1842). Vertebrate Zoology, 57: 23-33.

Knaack, J. 2007b. Beitraege zur Kenntnis der Callichthyidae (Teleostei: Siluriformes). III. Corydoras longipinnis sp. n. - ein neuer Panzerwels aus dem río Dulce in Argentinien (Teleostei: Siluriformes: Callichthyidae).Vertebrate Zoology, 57: 35-55.

Knaack, J. 2008. Beiträge zur Kenntnis der Callichthyidae (Teleostei: Siluriformes). IV. Der Lectotypus von Corydoras paleatus (Jenyns, 1842). Vertebrate Zoology, 58: 15-19.

Lacépède, B. G. E. 1803. Histoire naturelle des poissons. Paris, Chez Plassan, t. 5, 803p.

Larrañaga, D. A. 1923. Escritos de Don Dámaso Antonio Larrañaga. Volume 2. Montevideo: Instituto Histórico y Geográphico del Uruguay, Edición Nacional.

Lundberg, J. G. 1970. The evolutionary history of North American catfishes, family Ictaluridae. Unpublished Ph. D. Dissertation, The University of Michigan, Ann Arbor, Michigan, 524p.

Mo, T. 1991. Anatomy, Relationships and Systematics of the Bagridae (Teleostei: Siluroidei) with a Hypothesis of Siluroid Phylogeny (Theses Zoologicae, 17). Koenigstein: Koeltz.

Myers, G. S. \& S. H. Weitzman. 1960. Two new fishes collected by General Thomas D. White in eastern Colombia. Stanford Ichthyological Bulletin, 7: 98-109.

Nelson J. S. 2006. Fishes of the World. Hoboken, John Wiley \& Sons.

Nijssen, H. 1970. Revision of the Surinam catfishes of the genus Corydoras Lacépède, 1803 (Pisces, Siluriformes, Callichthyidae). Beaufortia, 18: 1-75.

Nijssen, H. 1971. Two new species and one new subspecies of the South American catfish genus Corydoras (Pisces, Siluriformes, Callichthyidae). Beaufortia, 19: 89-98.

Nijssen, H. 1972. Records of the catfish genus Corydoras from Brazil and French Guiana with descriptions of eight new species (Pisces, Siluriformes, Callichthyidae). Netherlands Journal of Zoology, 21: 412-433.

Nijssen, H. \& I. J. H. Isbrücker. 1976. Corydoras ornatus, a new species of callichthyid catfish from the rio Tapajós drainage, Brazil (Pisces, Siluriformes, Callichthyidae). Bulletin Zoölogisch Museum Universiteit van Amsterdam, 5: 125-129. 
Nijssen, H. \& I. J. H. Isbrücker. 1980. A review of the genus Corydoras Lacépède, 1803 (Pisces, Siluriformes, Callichthyidae). Bijdragen tot de Dierkunde, 50: 190-220.

Nijssen, H. \& I. J. H. Isbrücker. 1980. Three new Corydoras species from French Guiana and Brazil (Pisces, Siluriformes, Callichthyidae). Netherlands Journal of Zoology, 30: 494-503.

Nijssen, H. \& I. J. H. Isbrücker. 1986. Cinq espèces nouvelles de poissons-chats cuirassés du genre Corydoras Lacepède, 1803, du Pérou et de l'Equateur(Pisces, Siluriformes, Callichthyidae). Revue française d'Aquariologie Herpétologie, 12: 65-76.

d'Orbigny, A. 1847. Voyage dans L'Amérique Méeridionale (Le Bresil, La République Orientale de L'Uruguay, La République Argentine, La Patagonie, La République du Chili, La République de Bolivia, La République du Pérou), exécuté pendant les années 1826, 1827, 1828, 1829, 1830, 1831, 1832 et 1833. Tome 9, Atlas Zoologique (Mammiferes, Oiseaux, Reptiles, Mollusques, Polypiers, Foraminiferes, Crustacés et Insectes). Paris: Chez P. Bertrand.

Pesce, S. F., J. Cazenave, M. V. Monferrán, S. Frede \& D. A. Wunderlin. 2008. Integrated survey on toxic effects of lindane on Neotropical fish: Corydoras paleatus and Jenynsia multidentata. Environmental Pollution, 156: 775-783.

de Pinna, M. C. C. 1993. Higher-level Phylogeny of Siluriformes (Teleostei: Ostariophysi), with a New Classification of the Order. Unpublished Ph.D. Thesis, City University of New York, New York.

Pruzsinszky, I. \& F. Ladich. 1998. Sound production and reproductive behaviour of the armoured catfish Corydoras paleatus (Callichthyidae). Environmental Biology of Fishes, 53: 183-191.

Regan, C. T. 1911. The classification of the teleostean fishes of the order Ostariophysi. 2. Siluroidea. Annals and Magazine of Natural History, 8: 553-577.

Regan, C. T. 1912. A revision of the South American siluroid fishes of the genus Corydoras, with a list of the specimens in the British Museum (Natural History). Annals and Magazine of Natural History, 10: 209-220.

Reis, R. E. 1997. Revision of the Neotropical catfish genus Hoplosternum (Ostariophysi: Siluriformes: Callichthyidae), with the description of two new genera and three new species. Ichthyological Exploration of Freshwaters, 7: 299-326.

Reis, R. E. 1998. Anatomy and phylogenetic analysis of the Neotropical callichthyid catfishes (Ostariophysi, Siluriformes). Zoological Journal of the Linnean Society, 124: 105-168.

Reis, R. E. 2003. Family Callichthyidae (armored catfishes). Pp. 291-309. In: Reis R. E., S. O. Kullander, C. J. Ferraris (Eds). Check List of the Freshwater Fishes of South and Central America. Porto Alegre, Edipucrs.

Sands, D. D. 1990. A new species of callichthyid catfish, Corydoras araguaiaensis (Siluriformes, Callichthyidae) from the Rio Araguaia, Brazil. Pp. 1-2. In: Sands, D. (Ed.). Catfishes of the World. Suppl. Self published.

Schaefer, S. A. 1988. Homology and evolution of the opercular series in the loricarioid catfishes (Pisces: Siluroidei). Journal of Zoology, 214: 81-93.

Schaefer, S. A. \& A. E. Aquino. 2000. Postotic laterosensory canal and pterotic branch homology in catfishes. Journal of Morphology, 246:212-227.
Steindachner, F. 1876. Ichthyologische Beiträge (V). Sitzungsberichte der Kaiserlichen Akademie der Wissenschaften, Mathematisch-Naturwissenschaftliche Klasse, 74: 49-238.

Steindachner, F. 1879a. Über einige neue und seltene Fisch-Arten aus den k. k. zoologischen Museen zu Wien, Stuttgart, und Warschau. Denkschriften der Kaiserlichen Akademie der Wissenschaften, 41: 1-52.

Steindachner, F. 1879b. Über einige neue und seltene FischArten aus den zoologischen Museen zu Wien, Stuttgart und Warschau. Anzeiger der Kaiserlichen Akademie der Wissenschaften, 16: 29-34.

Taylor, W. R. \& G. C. Van Dyke. 1985. Revised procedures for staining and clearing small fishes and other vertebrates for bone and cartilage study. Cybium, 9: 107-119.

Tencatt, L. F. C., M. R. Britto \& C. S. Pavanelli. 2014. A new long-finned Corydoras Lacépède, 1803 (Siluriformes: Callichthyidae) from the lower rio Paraná basin, Brazil. Neotropical Ichthyology, 12: 71-79.

Tencatt, L. F. C., M. R. Britto \& C. S. Pavanelli. 2014. A new species of Corydoras Lacépède, 1803 (Siluriformes: Callichthyidae) from the upper rio Paraná basin, Brazil. Neotropical Ichthyology, 12: 89-96.

Tencatt L. F. C., H. S. Vera-Alcaraz, M. R. Britto \& C. S. Pavanelli. 2013. A new Corydoras Lacépède, 1803 (Siluriformes: Callichthyidae) from the rio São Francisco basin, Brazil. Neotropical Ichthyology, 11: 257-264.

Valenciennes, M. A. 1840. In: Cuvier, G., M. A. Valenciennes. Histoire naturelle des poissons. Tome 15. Paris, Chez $\mathrm{Cn}$. Pitois.

Valenciennes, M. A. 1847. Poissons. In: d'Orbigny A. Voyage dans L'Amérique Méeridionale (Le Bresil, La République Orientale de L'Uruguay, La République Argentine, La Patagonie, La République du Chili, La République de Bolivia, La République du Pérou), exécuté pendant les années 1826, 1827, 1828, 1829, 1830, 1831, 1832 et 1833. Tome 5, Part 2. Paris: Chez P. Bertrand, 1-11.

Vera-Alcaraz, H. S. 2013. Relações filogenéticas das espécies da família Callichthyidae (Ostariophysi, Siluriformes). Unpublished Ph.D. Dissertation, Pontifícia Universidade Católica do Rio Grande do Sul, Porto Alegre, 362p.

Weitzman, S. H. 1955. Redescription and relationships of Corydoras triseriatus von Ihering from the rio Doce, Brazil. The Wasmann Journal of Biology, 13: 101-106.

Weitzman, S. H. 1960. Figures and descriptions of four South American catfishes of the genus Corydoras, including two new species. Stanford Ichthyological Bulletin, 7: 140-154.

Weitzman, S. H. \& H. Nijssen. 1970. Four new species and one new subspecies of the catfish genus Corydoras from Ecuador, Colombia and Brazil (Pisces, Siluriformes, Callichthyidae). Beaufortia 18: 119-132.

Zarske, A. 2013. In memoriam Dr. rer. nat. Joachim Knaack (2.1.1933-5.12.2012). Vertebrate Zoology, 63: 249-252.

Submitted June 24, 2015 Accepted February 02, 2016 by Sven Kullander 